\title{
Geomorphology and Prehistoric Settlements on a Volcanic Island: the Case of Ustica (Palermo, Italy)
}

\author{
Franco Foresta Martin*,1,2, Stefano Furlani ${ }^{3,4}$ \\ (1) Istituto Nazionale di Geofisica e Vulcanologia, Sezione di Palermo, Italy \\ (2) Laboratorio Museo di Scienze della Terra Isola di Ustica, Palermo, Italy \\ (3) Dipartimento di Matematica e Geoscienze, Università di Trieste, Italy \\ (4) Science and Technology for Cultural Heritage (SCICC), Interdipartimental Centre, University of Trieste, Italy
}

Article history: received June 20, 2021; accepted September 9, 2021

\begin{abstract}
This study represents the first attempt to combine the geomorphological characteristics of the island of Ustica with the human settlements that have been established during prehistory, with the purpose of reconstructing the interactions between communities and the natural environment from the Neolithic to the Middle Bronze Age ( $6^{\text {th }}-1^{\text {st }}$ millennia B.C.). Ustica is a small island in the Southern Tyrrhenian Sea, visible but far ( $55 \mathrm{~km})$ from the northern coast of western Sicily. Its rugged volcanic nature, remodeled and enriched by the sea, offered to the first colonizers a wide repertoire of opportunities and challenges. This island can be treated as an ideal "laboratory" to understand how settlers, taking their first steps towards the foundation of organized communities, were able to seize opportunities or succumb to obstacles. The review of archaeological research until now carried out in Ustica, integrated with geomorphological data and other biogeographical indicators, offers a picture of the prehistory of Ustica in which human presence is continuous and distributed in various sites of the island characterized by different physiographic characteristics. There are phases dominated by the choice of naturally protected sites and phases in which settlements expands on open land, suitable for agricultural use. Where the archaeological evidence is scarce, the geomorphological peculiarities allow us to decipher the vocations and characters of a human settlement. The study leads to an open question: in the Middle Bronze Age, after about five thousand years of uninterrupted habitation of Ustica, which factors, geological, social, or other, induced the early communities to abandon the island, without returning there for about eight centuries, until the Hellenistic-Roman age?
\end{abstract}

Keywords: Geoarchaeology; Tyrrhenian Sea; Prehistoric Settlements; Island Archaeology; Volcanic Landscape.

\section{Introduction}

An island of volcanic nature, forged by the eruptions and shaped by the sea, represents a privileged case study to analyze how geomorphology, environment, and natural resources influenced the choice of the first human 


\section{Franco Foresta Martin et al.}

settlements in prehistoric times. For such research, we have chosen Ustica, a small $\left(<10 \mathrm{~km}^{2}\right)$ and solitary island characterized by low hills ( $<250 \mathrm{~m}$ asl), and positioned in the Southern Tyrrhenian Sea, $55 \mathrm{~km}$ off the northwestern coast of Sicily (Figure 1). The island offers both specific volcanic landscapes and a human history scattered across time and rich in archaeological heritage.

The volcanic activity of Ustica began and ended in the Pleistocene and has been extinct for over one hundred thousand years [de Vita and Foresta Martin, 2017]. The island preserves many typical landforms of volcanic origin such as crater relics, columnar lavas, thick pyroclastic deposits, dykes, and pillow-lavas, above and below the sea level [Romano and Sturiale, 1971; de Vita, 1993; Furlani et al., 2017], and can be considered as an open-air museum of volcanology that scholars can safely explore and study [Foresta Martin, 2014].

The wild and unspoiled nature of Ustica offered its first prehistoric colonizers benefits and drawbacks, dangers and safety, at the same time. The sea has shaped the coastal perimeter of Ustica with a lot of bays and coves that provide easy landing places for small boats and shelter against recurrent adverse weather conditions. Several caves along the coast, together with some in the hinterland, offered shelter for humans and animals but above all, they provided the first colonizers with a precious resource such as drinking water. The latter drips from the vaults, and in prehistoric times it was vital as the island has no underground springs. The indented coast hosts various kinds of mollusks, many of which are edible and easy to collect; and also many species of small fish suitable for fishing with the most primitive tools. Again the sea, in the course of the glacio-eustatic oscillations, abraded and filled with sediments wide sectors of the island, creating large terraced areas [de Vita and Orsi, 1994] where the mixing of marine and volcanic sedimentary deposits produced a soil rich in nutrients, then exploited by communities as fertile fields for crops.

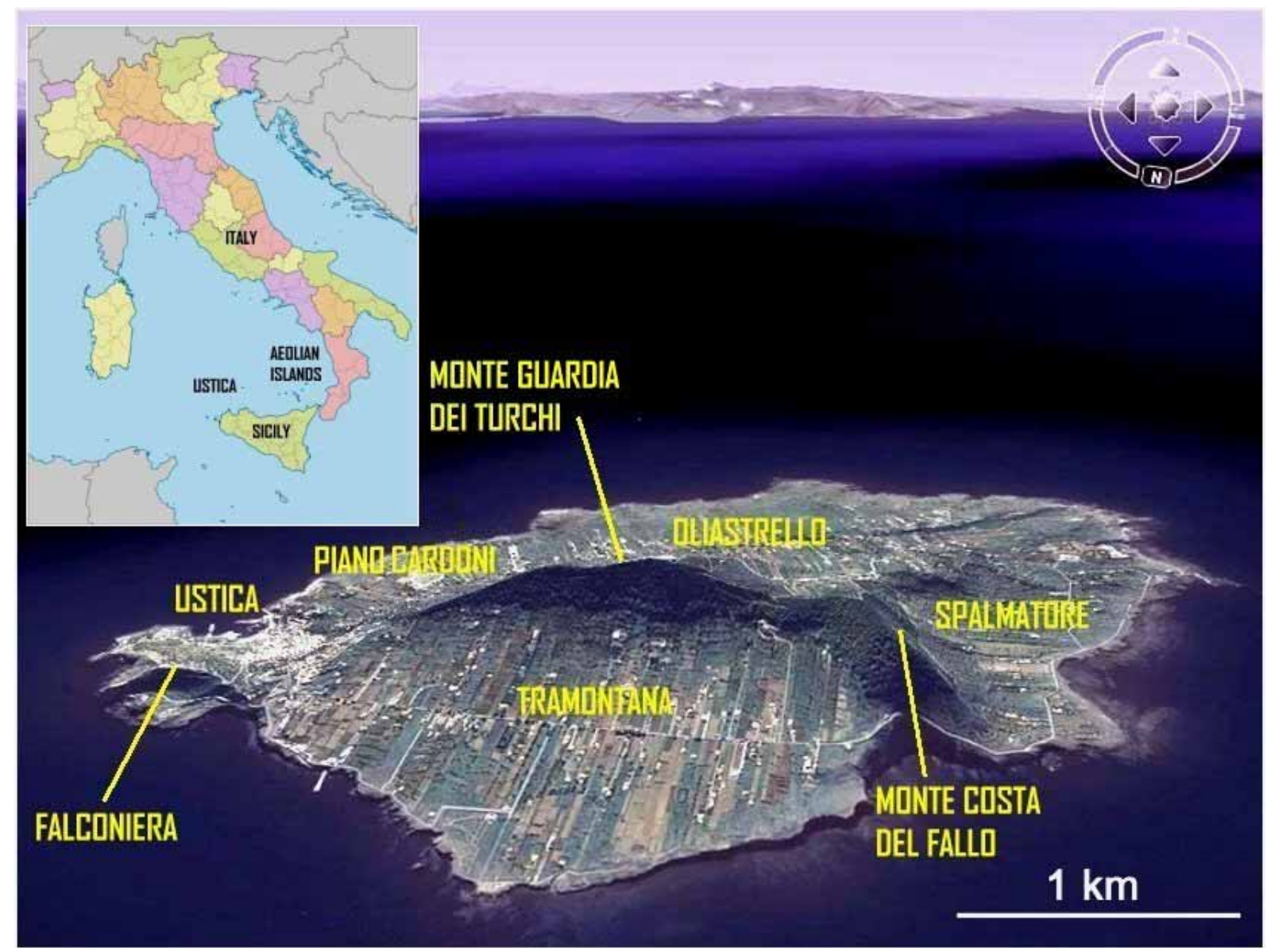

Figure 1. The island of Ustica (Sicily) in the Southern Tyrrhenian Sea. In the background, the northwestern coast of Sicily (Modified from Google Earth). 
This paper relates, for the first time, the main human settlements so far ascertained in Ustica during prehistoric times, with the geomorphological characteristics and the vital resources of the territory. For each site, we have considered features such as the geological substrate, altitude, orientation, distance from the sea, visibility of the marine horizon, proximity to natural resources, with the purpose to identify which main factors influenced the settlement choices. The study takes into consideration about five millennia of Sicilian prehistory, from the Neolithic to the Middle Bronze Age ( $6^{\text {th }}-1^{\text {st }}$ millennia B.C.) which, according to the archaeological literature, represents a period of intense and continuous habitation of the island of Ustica, followed by centuries of abandonment for reasons still unknown [Spatafora and Mannino, 2008].

\section{Study Area}

\subsection{Geovolcanological Framework}

The island of Ustica is the top of an underwater volcanic mountain whose base rests on the bottom of the southern Tyrrhenian Sea at a depth of more than $2000 \mathrm{~m}$. It is located $\sim 55 \mathrm{~km}$ north of the Sicily coast (at the minimum distance) and $\sim 150 \mathrm{~km}$ west of the Aeolian Islands (taking Lipari as the center of the archipelago). The shape of Ustica can be compared to an ellipse with the major axis of $4.5 \mathrm{~km}$ oriented NE-SW, and the minor axis of $2.5 \mathrm{~km}$ oriented NW-SE. The island has an area of $8,6 \mathrm{~km}^{2}$ and reaches a maximum elevation of $248 \mathrm{~m}$ a.s.l. at Monte Guardia dei Turchi (Figure 1 and 2).

The origin of Ustica's volcanism is related to the activation of left-transtensional deep faults, linked to the deformational events that accompanied the anticlockwise rotation of the Italian peninsula and the opening of the Tyrrhenian basin, due to the complex interaction between the African and Eurasian plates [de Vita et al., 1995].

Volcanism in the area of Ustica began after the activation of submarine vents opened on NE-SW-oriented faults. The age of this activity, which built the submerged part of the volcano, is not precisely known, as the lavas that erupted in this phase are located at abyssal depth and have not been analyzed yet. But the upper part of this primitive lavas is exposed along the southern coast of the island and has a radiometric age of $\sim 735 \mathrm{ka}$; therefore it is believed that Ustica volcanism began shortly before, in the Middle Pleistocene [Barberi et al., 1969; Barberi and Innocenti, 1980; de Vita, 1993; de Vita et al., 1998].

Volcanic rocks and marine sedimentary deposits are the main geological constituents of the island (Figure 2). Volcanic rocks are the product of both subaqueous and subaerial effusive and explosive eruptions [Romano and Sturiale, 1971; Cinque et al., 1988; de Vita, 1993; de Vita et al., 1995; 1998; de Vita and Foresta Martin, 2017]. The volcanic products of Ustica exhibit terms from alkali-basalts to alkali-trachyte, with a gap in the field of benmoreite, and have a Na-alkaline affinity [de Vita, 1993; Peccerillo, 2005]. Since the magmas that generated these volcanites originate from an intraplate type mantle, Ustica has been defined as the only volcano of anorogenic origin that emerged from the South Tyrrhenian Sea [de Vita and Foresta Martin, 2017]. Marine sedimentary rocks of Ustica consist of clayey sands, organogenic and detrital fossiliferous limestones, and carbonate concretions, formed during Middle-Upper Pleistocene sea-level high-stands, related to glacio-eustatic movements that also generated five orders of marine terraces, [de Vita and Orsi, 1994], (Figure 2).

\subsection{Chronology of major geovolcanological events}

Volcanic activity at Ustica was for a long time submarine, fed by mantle magma emerging from multiple eruptive vents located on the seabed and following the NE-SW oriented fault system; afterward, the activity concentrated in a restricted area, with the formation of a main magmatic conduit, and the slow growth of a big seamount [de Vita, 1993; Foresta Martin, 2014].

The top of the seamount emerged $\sim 520 \mathrm{ka} B$, becoming the first subaerial volcano of the island, now Monte Guardia dei Turchi, $248 \mathrm{~m}$ a.s.l., located in the center of the island [de Vita et al., 1998; Foresta Martin, 2014]. The effusive and strombolian eruptions of Monte Guardia dei Turchi went on for $\sim 20 \mathrm{ka}$, after which the activity moved westward to the second-highest volcanic mount of the island, Monte Costa del Fallo, 238 m. a.s.l., characterized by recurring interactions between the magma and the seawater, and accompanied by an intense explosive activity that lasted up to $\sim 475 \mathrm{ka}$ BP 


\section{Franco Foresta Martin et al.}

[de Vita et al., 1998; Foresta Martin, 2014]. At this point, the dating performed on the eruptive products reveal a long stasis: for $\sim 50$ ka the magma differentiated in a shallow chamber, changing its composition from basic to acid. The resumption of volcanic activity took place with a sub-plinian eruption, from a vent that is thought to have been located on the northern side of the island, in the Tramontana plain. The explosion caused a high eruptive column and the fallout of abundant ash and pumice which are found as deposits in several parts of the island, known as Grotte del Lapillo Tephra [de Vita et al., 1998; Foresta Martin, 2014].

Afterward, the volcanic activity continued with a series of minor effusive eruptions: Cala Sidoti ( $\sim 20 \mathrm{ka})$, Timpone Tranchina ( $\sim 12 \mathrm{ka})$, Case Zacame ( $\sim 330 \mathrm{ka})$, Villaggio di Spalmatore ( $\sim 300-320 \mathrm{ka})$, Gorgo Salato ( $\sim 325 \mathrm{ka})$, Tramontana ( $320 \mathrm{ka}$ ) [de Vita et al., 1998; Foresta Martin, 2014], (Figure 2). The island's volcanic activity ended about $130 \mathrm{ka} \mathrm{BP,} \mathrm{with}$ the explosive Monte Falconiera (157 $\mathrm{m}$ a.s.l.) hydromagmatic eruption and the formation of a tuff-cone, whose northern sector later collapsed into the sea. The southern part of the Falconiera cone still resists and represents the most easily recognizable of Ustica's craters [Romano and Sturiale, 1971; de Vita et al., 1995, 1998; de Vita and Foresta Martin, 2017].

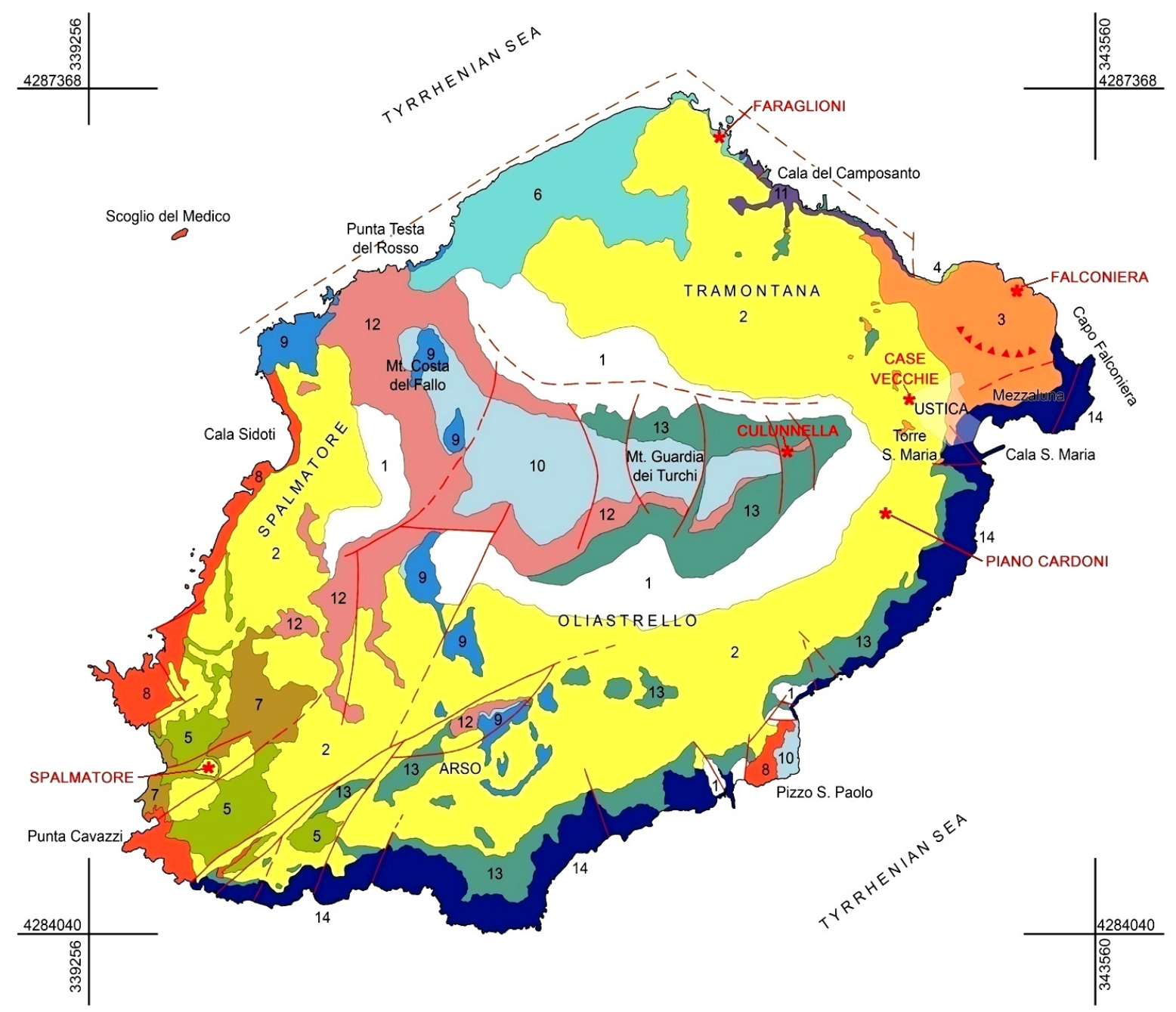

Figure 2. Simplified geologic map of Ustica. Modified from de Vita and Foresta Martin (2017). Legend: 1. Slope debris. 2. Marine terrace deposits (350-80 ka). 3. Falconierta Tuff Cone ( 130 ka). 4. Cala Giaconi Hyaloclastic Ring $(\sim 150$ ka). 5. Spalmatore Subaereal Lavas ( 320-300 ka). 6. Tramontana Subaereal Lavas ( $320 \mathrm{ka})$. 7. Case Zacame Tuff Ring ( $330 \mathrm{ka})$. 8. Spalmatore and Pizzo San Paolo Submarine Lavas ( 400-350 ka). 9. Timpone Tranchina Subaereal Lavas ( 410 ka). 10. Grotte del Lapillo Tephra ( 425 ka). 11. Camposanto Hyaloclastites and Subaereal Lavas ( 500-475 ka). 12. Costa del Fallo Tuff Cone and Subaereal Lavas ( 500-520 ka). 13. Monte Guardia dei Turchi subaereal lavas (520-500 ka). 14. Cala S. Maria Submarine Lavas and Breccias ( $735 \mathrm{ka})$. The red asterisks highlight the archaeological sites where evidence of stable human occupation in prehistoric times was found: Spalmatore (Pirozza), Piano dei Cardoni, Culunnella, Case Vecchie, Faraglioni, and Falconiera (Punta Omo Morto). 
Ustica's volcanic history has been punctuated by several overlapping cycles of marine ingressions and regressions, resulting from the climate change and associate sea-level variations during the Middle-Upper Pleistocene stages, between 350 and $80 \mathrm{ka} \mathrm{BP}$. These glacio-eustatic movements caused the stationing of the sea on land, with the formation of five typical sedimentary terraces that cover the Piano dei Cardoni, Oliastrello, Tramontana, Arso, and Spalmatore areas, displaced at a variable height above sea level, from $5 \mathrm{~m}$ to $120 \mathrm{~m}$ a.s.l. [de Vita and Orsi, 1994], (Table 1, Figure 2). Some sediments of these marine terraces are richly fossiliferous [Buccheri et al., 2014; de Vita and Foresta Martin, 2017].

\begin{tabular}{cccc} 
ORDER & HEIGHT (m a.s.l.) & AGE (ka) & MIS \\
\hline I & $80-120$ & 350 & 9 \\
\hline II & $40-60$ & $240 \pm 35$ & 7 \\
\hline III & 30 & $132 \pm 6$ & $5 \mathrm{e}$ \\
\hline IV & 10 & 105 & $5 \mathrm{c}$ \\
\hline V & 5 & 80 & $5 \mathrm{a}$ \\
\hline
\end{tabular}

Table 1. Order, elevation, age, and marine isotopic stage [Shackleton and Hopdike, 1973] of the marine terraces of Ustica. From de Vita and Orsi [1994].

\subsection{The Geomorphological Framework}

The morphology of the island is the result of the prolonged interplay between volcanism, tectonism, eustatism, and exogenous morphodynamic processes that generated volcanic structures and leveled surfaces (Figure 3). The island is morphologically characterized by an east-west alignment of three small mountains, relics of extinct volcanoes: Monte Guardia dei Turchi (in the center), Monte Costa del Fallo (to the west), and Falconiera (to the east). These reliefs form a ridge that divides the island into two asymmetrical sectors, the northern and southern, both dominated by large flat surfaces arising from terracing operated by the sea during the transgressive-regressive cycles of the late-Pleistocene epoch. The northern and larger terraced sector is connected to the central reliefs with steep slopes; whereas the southern terraces join the reliefs with less steep slopes [Romano and Sturiale, 1971; Cinque et al., 1988; de Vita, 1993].

The structural pattern of the island is marked by numerous faults, mostly normal, with prevalent ENE-WSW and NE-SW trends, which represent the local footprint of fault systems acting on a regional scale. The most prominent fault, the Faglia dell'Arso fault, in the southwestern sector, borders the homonymous reliefs that overlook the southwestern coast of the island [Cinque et al., 1988; de Vita, 1993].

Ustica has a coastline of about $16 \mathrm{~km}$ that can be divided into four sectors:

- The Southern sector, or Costa di Mezzogiorno, runs from Cala S. Maria to Punta Cavazzi, passing through the headlands of S. Paolo, Galera and Arpa. It is characterized by high ( $\sim 80 \mathrm{~m}$ a.s.l.) and jagged cliffs descending into the sea with steep slopes. Here, the products of submarine eruptions, in the form of basaltic pillows and hyaloclastites, alternate with products of subaerial eruptions made of basaltic and Hawaiian lava flows [Foresta Martin, 2015; Furlani et al. 2017].

- The Western sector or Spalmatore, between the Cavazzi and Megna headlands, is characterized by the lowest and most indented coast of the entire perimeter of the island and is formed by a succession of subaerial and submarine volcanites, the latter represented by abundant ialoclastic breccia [Foresta Martin, 2015; Furlani et al., 2017].

- The Northern sector, or Tramontana, is made up of sea cliffs changing in orientation because of two almost straight long fractures (Figure 2). A stretch of the sea cliff, 10 to $40 \mathrm{~m}$ in height starts from Punta di Megna up to Punta Gorgo Salato and it results from a NE-SW oriented fault. Another stretch of cliff, about $20 \mathrm{~m}$ in height, starts from Punta del Gorgo Salato up to Cala Giaconi, passing through Cala del Camposanto. It 


\section{Franco Foresta Martin et al.}

originates from a fault aligned in the NW-SE direction. Here, sea cliff retreat and repeated collapses of the cliff wall generated two large stacks, called respectively Nerone and Colombaio [Foresta Martin, 2015; Furlani et al., 2017; Furlani and Foresta Martin, 2019].

- The Eastern sector or Falconiera promontory. It is a relic of the volcanic tuff-cone called Falconiera which was active about 130 thousand years ago. On the northern side, this volcano exposes the bottom of the crater half-collapsed into the sea, and the neck inside it [Foresta Martin, 2015; de Vita and Foresta Martin, 2017; Furlani et al. 2017].

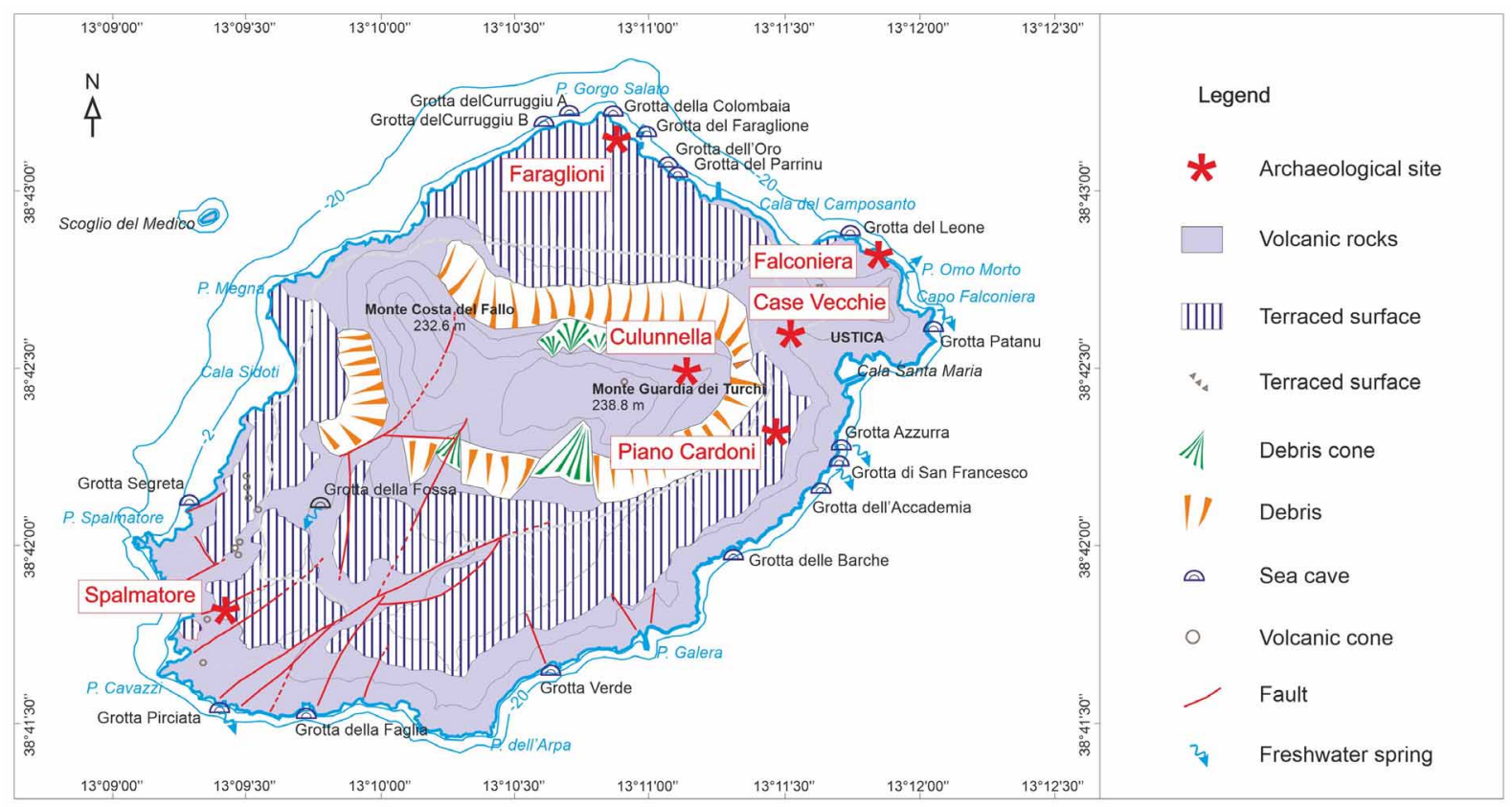

Figure 3. Simplified geomorphological map of Ustica Island [Furlani, this work].

\subsection{The Prehistoric Colonization of Ustica}

Prehistory, from the Neolithic to the Middle Bronze Age, i.e. $6^{\text {th }}-1^{\text {st }}$ millennium BC, was a period of intense frequentation and population of the island of Ustica, as evidenced by the ruins of villages and the abundance of potsherds and obsidian fragments scattered throughout the island [Spatafora and Mannino, 2008; Mannino and Ailara, 2016].

In the last half-century, archaeological research carried out in Ustica has focused, above all on the Middle Bronze Age village called Faraglioni, one of the best-preserved settlements in the Central Mediterranean, where several excavation campaigns were carried out, as described below. All the other settlements of archaeological importance, that cover the long period from the Neolithic to the Middle Bronze Age, were identified through occasional surface surveys and they still lack systematic excavation campaigns. Recently, new excavations essays have brought to light an important Neolithic settlement in the Piano dei Cardoni area [Speciale et al, 2020; Speciale et al, 2021a,b], partly intuited by surface surveys at the end of the last century [Mannino, 1991, 1997]. It is the demonstration of the richness of the still unexplored archaeological heritage existing on the island.

In the following paragraphs, based on the literature, we will review the so far attested human prehistoric settlements located in Spalmatore, Piano dei Cardoni, Culunnella, Case Vecchie, Faraglioni, and Omo Morto (Figure 2), whose occupation phases are summarized in Table 2. It will be the necessary premise to discuss the correlations between human settlements and the geomorphological characteristics of the island. 
Ustica Geomorphology and Ancient Settlements

PERIOD

SPALM

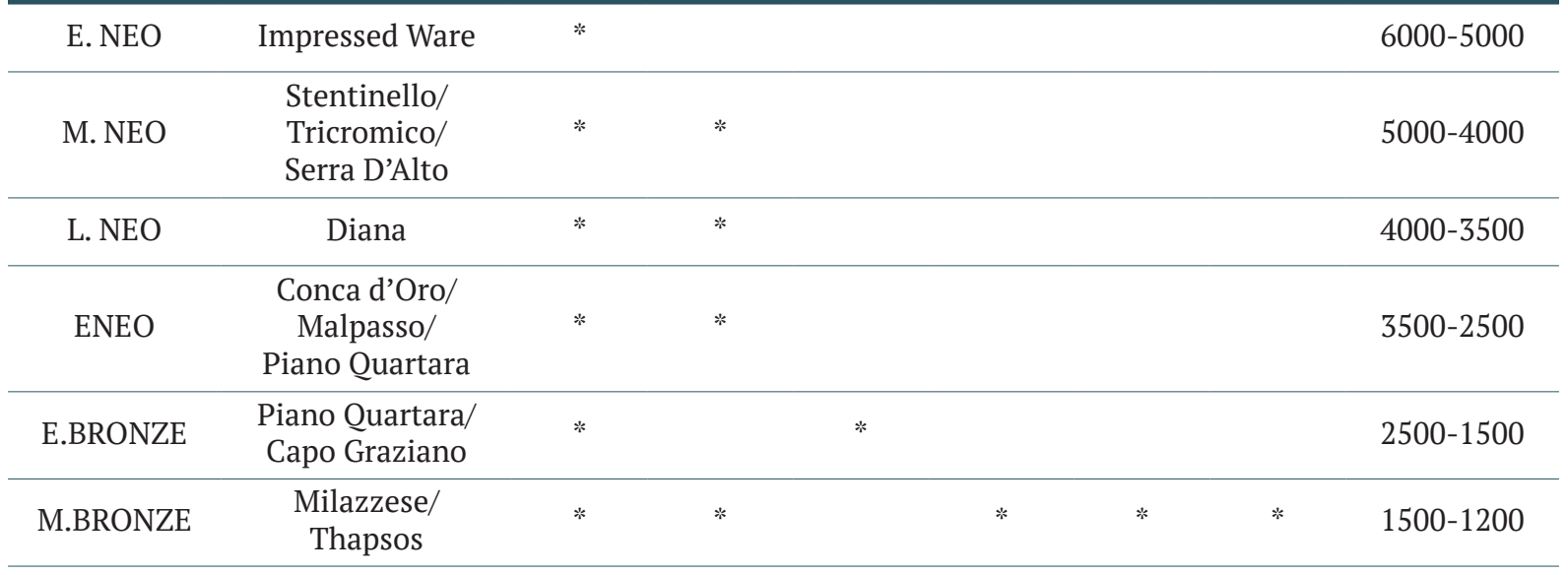

Table 2. Phases of occupation of Ustica during Prehistory (from: Mannino [1991; 1998a]; Spatafora and Mannino [2008]; Mannino and Ailara [2016]; Speciale et al. [2021a,b]). E.Neo=Early Neolithic; M.Neo=Middle Neolithic; L.Neo=Late Neolithic; Eneo=Eneolithic; E. Bronze=Early Bronze Age; M. Bronze=Medium Bronze Age; Spalm=Spalmatore; P.Card=Piano dei Cardoni; Culun=Culunnella; Case V.=Case Vecchie; Fara=Faraglioni; Falc=Falconiera.

\subsubsection{Spalmatore Settlements, from Neolithic to Bronze Age}

The first Neolithic Age settlement was probably located on the flat top of Pirozza hill, at $50 \mathrm{~m}$ a.s.l., a small promontory facing the sea on the southwestern sector of Spalmatore, (Figures 3 and 4). Archaeological excavations have never been carried out on Pirozza hill, but the abundant ceramic finds emerged from the ground permitted the recognition of three styles of pottery: Stentinello, Trichrome, and Diana, which correspond respectively to the Middle and Late Neolithic phases, covering a period from the $6^{\text {th }}$ to $4^{\text {th }}$ millennium BC [Mannino, 1998a; 2015], (Figure 5 and Table 2). Based on stylistic analogies of these ceramic finds, Mannino [1998a, 2015] suggested that the first Neolithic population that landed at Ustica came from Neolithic villages near Palermo.

Archaeological evidence points out that the settlement lasted well beyond the Neolithic age, expanding into the flat areas around the Pirozza hill, as attested by the ceramic finds of the Eneolithic Age (Conca D'Oro and Malpasso phases), the Early Bronze (Piano Quartara and Capo Graziano), and the Middle Bronze (Milazzese and Thapsos) [Mannino, 1998a, 2015; Spatafora and Mannino, 2008; Mannino and Ailara, 2016]. Although the construction of a tourist resort caused the partial destruction and/or mixing of the archaeological remains, based on the abundance of diagnostic ceramic fragments this area was continuously inhabited until the Middle Bronze Age [Mannino and Ailara, 2016].

In the area of Pirozza, fragments of obsidian tools and wastes were also discovered [Mannino, 1998a] and analyzed [Foresta Martin and Tykot, 2019]. As the volcanism of Ustica did not produce volcanic glasses, the obsidian was imported from elsewhere. The results of geochemical analyses point to the obsidian sources on the islands of Lipari and Pantelleria, therefore attesting to the far exchanges between Ustica and these two Sicilian islands during the prehistory [Foresta Martin and Tykot, 2019].

\subsubsection{Piano dei Cardoni Settlements, from Neolithic to Bronze Age}

Another key site of prehistoric presence at Ustica is Piano dei Cardoni, located in the southern hinterland of the island, at an altitude ranging from about 80 to120 m a.s.l. (Figures 2 and 6). Until recently, the knowledge of the archaeological history of this part of the island was based exclusively on the collection of surface finds, which indicated the presence of ceramic fragments in the so-called Conca d'Oro style, dating back to the $4^{\text {th }}-3^{\text {rd }}$ millennium $\mathrm{BC}$, that is the Eneolithic (or Chalcolithic) period, and also potsherds attributable to the Middle Bronze Age [Mannino, 1991, 1997; Spatafora and Mannino, 2008; Mannino and Ailara, 2016]. But during the years 2018-2020, some 


\section{Franco Foresta Martin et al.}

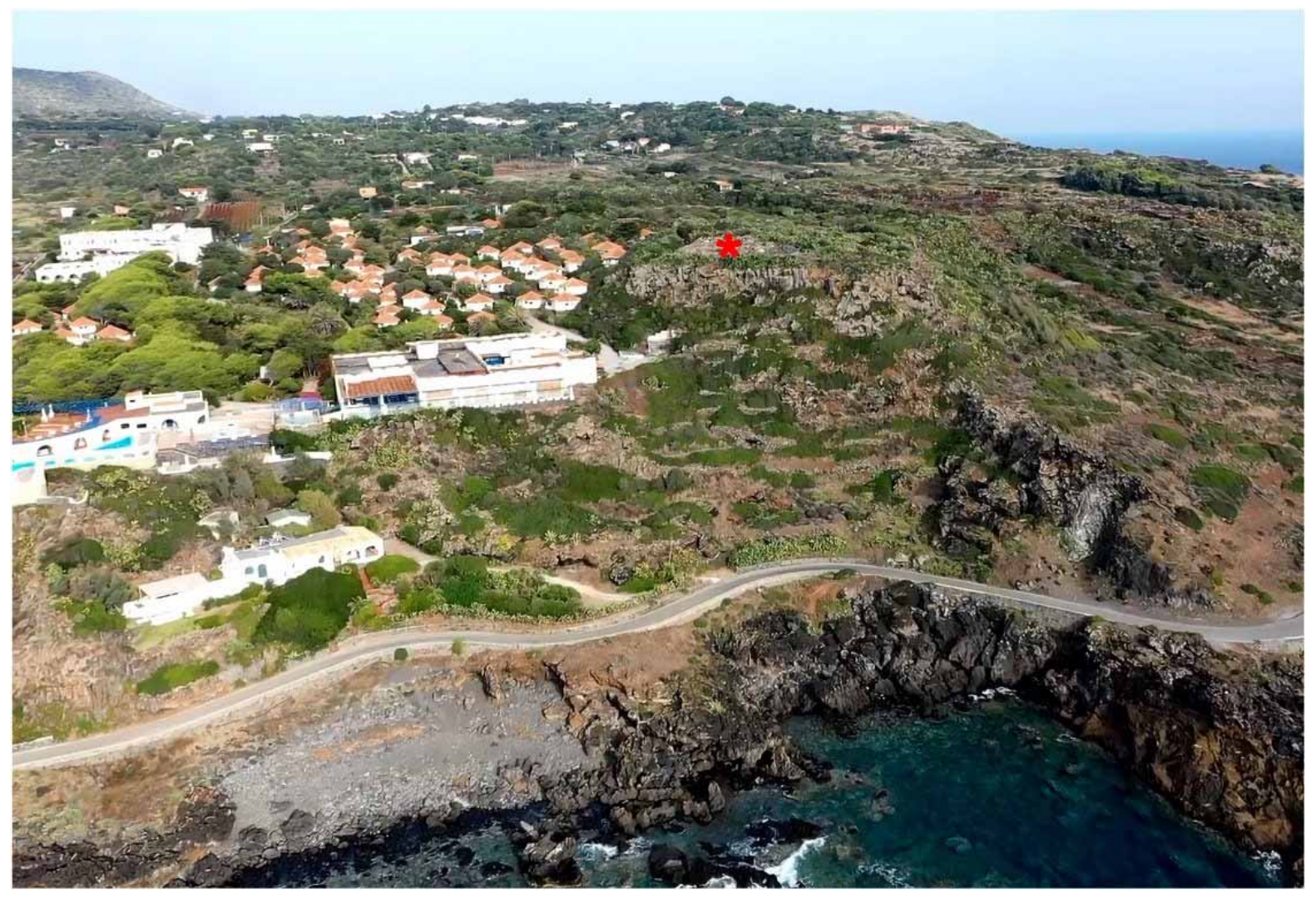

Figure 4. Pirozza Hill (evidenced with a red asterisk) was probably the first Neolithic settlement on the island of Ustica. On the left, at a low altimetric level, the bungalows of the touristic resort Punta di Spalmatore. Drone photo by INGV.

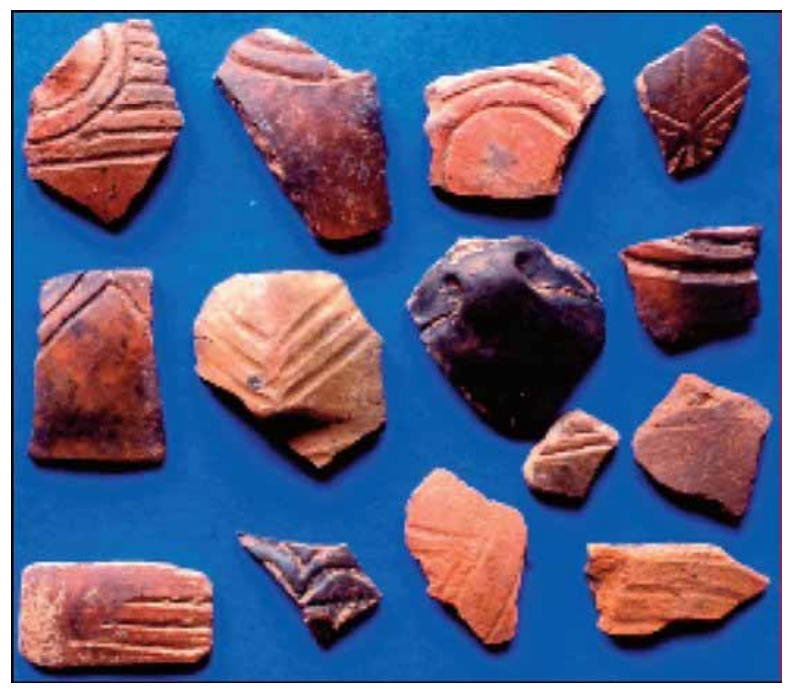

Figure 5. Some Neolithic-style ceramics with excised and incised decorations, collected at the northern feet of Pirozza Hill. From Mannino and Ailara [2016]. 


\section{Ustica Geomorphology and Ancient Settlements}

excavation campaigns brought to light artifacts of the Neolithic Age attributed to Serra D'Alto, and Diana styles, which are datable from the mid to late $5^{\text {th }}$ millennium $\mathrm{BC}$, as confirmed also by mass spectrometry analyses [Speciale et al., 2020; Speciale et al., 2021a,b]. The analysis of the abundant finds recovered in this excavation is still ongoing.

Over many years, thanks to some surface archaeological surveys carried out in the Piano dei Cardoni area, dozens of obsidian fragments were collected; most of them, 85-90\%, are attributable to Lipari and the remaining part to Pantelleria [Foresta Martin and La Monica, 2019; Tykot and Foresta Martin, 2020; Speciale et al., 2021a,b]. All these findings attest to the presence of a prehistoric settlement that arose in the Neolithic Age and continued afterward (Table 2).

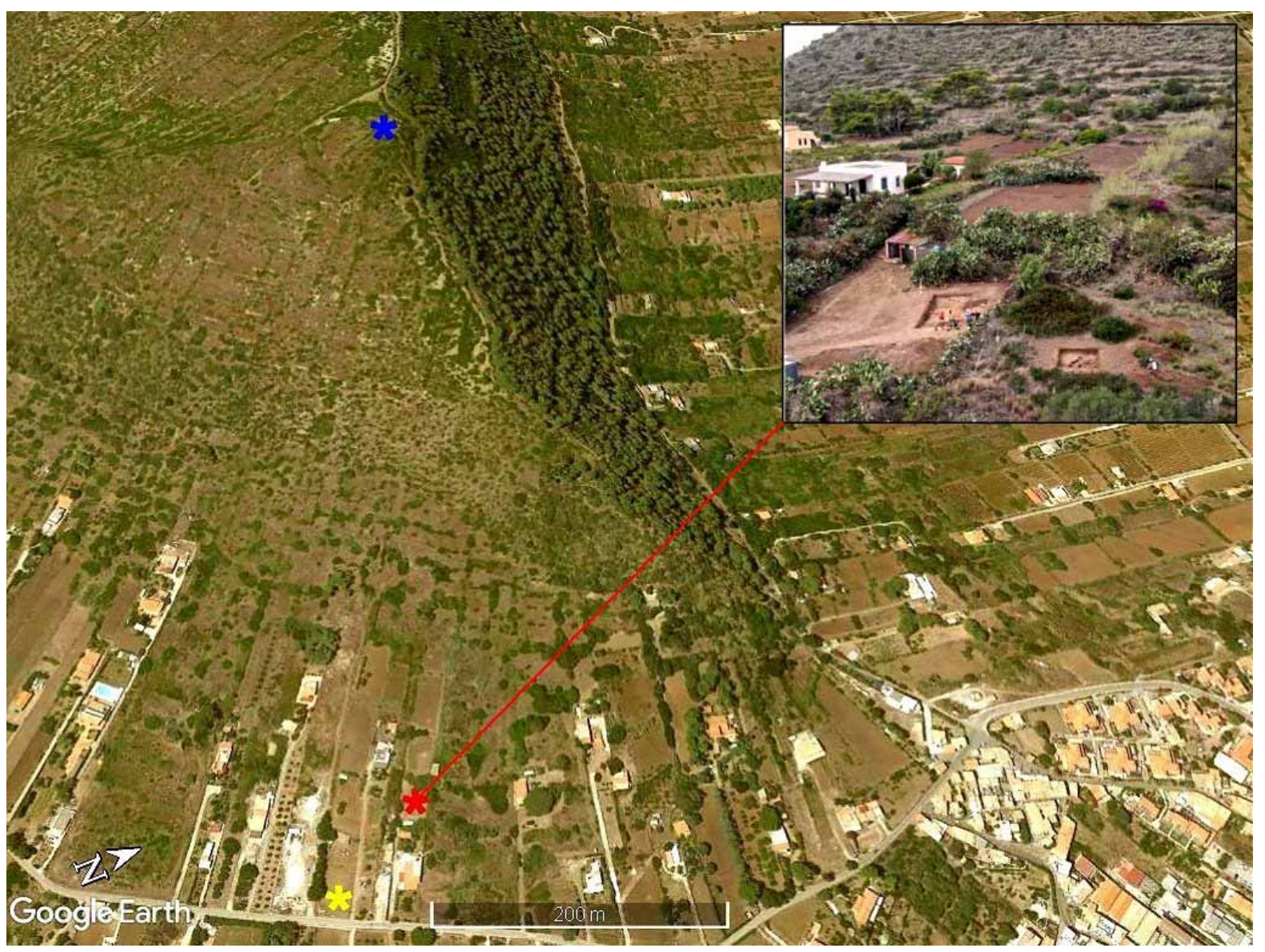

Figure 6. Aerial view of the Piano dei Cardoni area (bottom-left) and Monte Guardia dei Turchi - Culunnella reliefs (topleft). In the Piano dei Cardoni area, evidence of a Neolithic-Eneolithic settlement (respectively red and yellow asterisks) was collected. In the insert, the excavation area of the Neolithic settlement, from Speciale et al. [2021c]. A few hundred meters above, on the Culunnella hill (blue asterisk), there are traces of an Early Bronze Age settlement and a coeval necropolis. Modified from Google Earth.

\subsubsection{The Culunnella Ancient Bronze Age Settlement}

About 600 meters away from the Piano dei Cardoni settlement, on the heights of Monte Guardia dei Turchi, the archaeologist G. Mannino [1991], at the beginning of the 90s of the last century discovered the traces of a small prehistoric village and an adjoining necropolis. The village was located on the top of the Culunnella hill, at $238 \mathrm{~m}$ a.s.l., on an area of about 2000 square meters that had been artificially leveled and surrounded with defensive boulders transported there by settlers [Mannino, 1991]. The necropolis, of which only four rock-cut tombs of the "grotticella" type with well-shaft entrances have been identified, was built at a slightly lower altitude [Mannino, 1991; Mannino and Ailara, 2016]. Fragments of "impasto" (a type of hand-made, not wheel-thrown) pottery, 


\section{Franco Foresta Martin et al.}

decorated in the style of Capo Graziano (Eolie Islands), were collected on the surface of both sites, therefore it was possible to date them to the Early Bronze Age (2500-2000 BC), [Mannino, 1991, 1997, 2008; Mannino and Ailara, 2016]. However, despite the importance of these findings, an archaeological excavation campaign has not yet been carried out in this area.

\subsubsection{The Middle Bronze Age Villaggio dei Faraglioni}

Archaeologists estimate that in the Middle Bronze Age Ustica was populated by several hundred inhabitants, distributed in settlements in various parts of the island. The largest and most important settlement of this period was the Villaggio dei Faraglioni, which had a short but intense life (1400-1200 BC), and was inserted in the periTyrrhenian commercial routes connecting the coasts of Sicily and the Aeolian Islands with other centers of the Italian peninsula [Spatafora, 2009; 2016; Spatafora and Mannino, 2008; Tusa, 2016].

The Villaggio dei Faraglioni took its name from the Faraglione Colombaio and Faraglione Nerone, two stacks ("faraglione" in Italian) emerging from the sea on the northern side of the island. The village was settled in a stretch of coast bordered by $20 \mathrm{~m}$-high sea cliffs and covered with a marine terrace at the top (Figure 7). The cliff, as we will see below, is subject to continuous collapses and these phenomena are likely to have affected the life of the village. Since the 70s of the last century, several archaeologists have carried out excavation campaigns in this area, bringing to light the remains of a settlement defined as one of the best-preserved Middle Bronze Age town of the Mediterranean region [Mannino, 1970, 1979, 1982; Holloway and Lukesh, 1995, 2001; Spatafora, 2005; Spatafora and Mannino, 2008; Counts and Tuck, 2009].

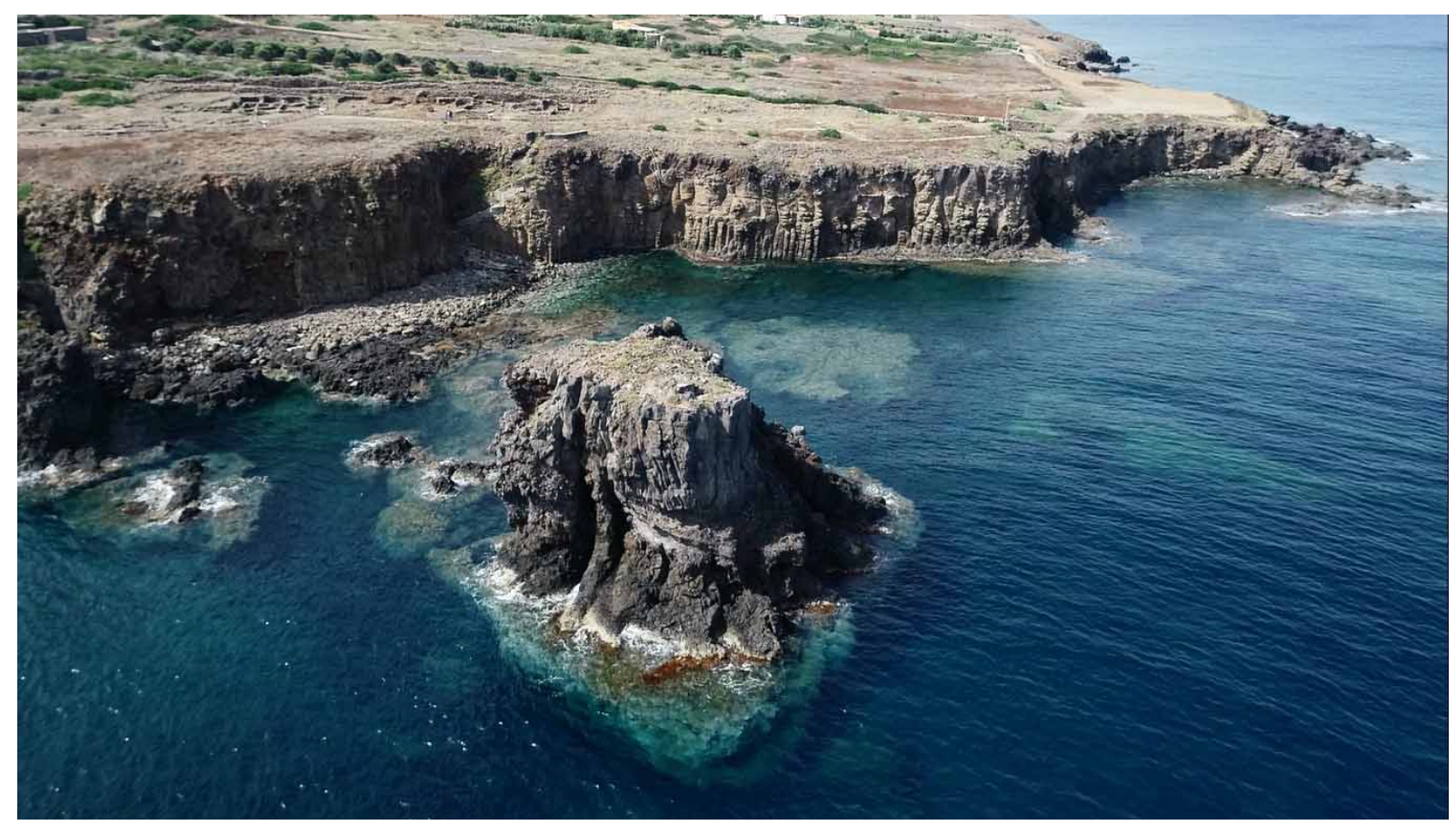

Figure 7. UAV view of Villaggio dei Faraglioni, the Middle Bronze Age settlement on the northern side of the island. In the foreground the Faraglione Colombaio. On the top left, the bottoms of huts unearthed by excavations, and the defensive wall. Courtesy of INGV.

On the landward side, a mighty fortified wall $250 \mathrm{~m}$ long and $4 \mathrm{~m}$ high, strengthened by thirteen buttresses, was built to protect the village. It delimits an area of about $7000 \mathrm{~m}^{2}$ where several huts, placed next to one another, have been unearthed at the sides of streets about one meter wide (Figure 8). Groups of adjacent huts shared courtyards, 
where containers for food and big "pithoi" or large jars for the collection of rainwater were placed. A sort of urbanistic plan similar to that of the famous and coeval village of Thapsos, in the Magnisi peninsula, near Syracuse, Eastern Sicily, characterized the settlement [Holloway and Lukesh, 1995, 2001; Spatafora and Mannino, 2008], (Figure 7). The number of huts built in the area of the Village has been the subject of debate among the different excavators: Mannino [1982: 281] suggests a few hundred, assuming also an extension of the village in parts that later collapsed into the sea; Holloway and Lukesh [1997: 460] only a few dozen. Extending the excavations to still unexplored areas will help to clarify the answer.

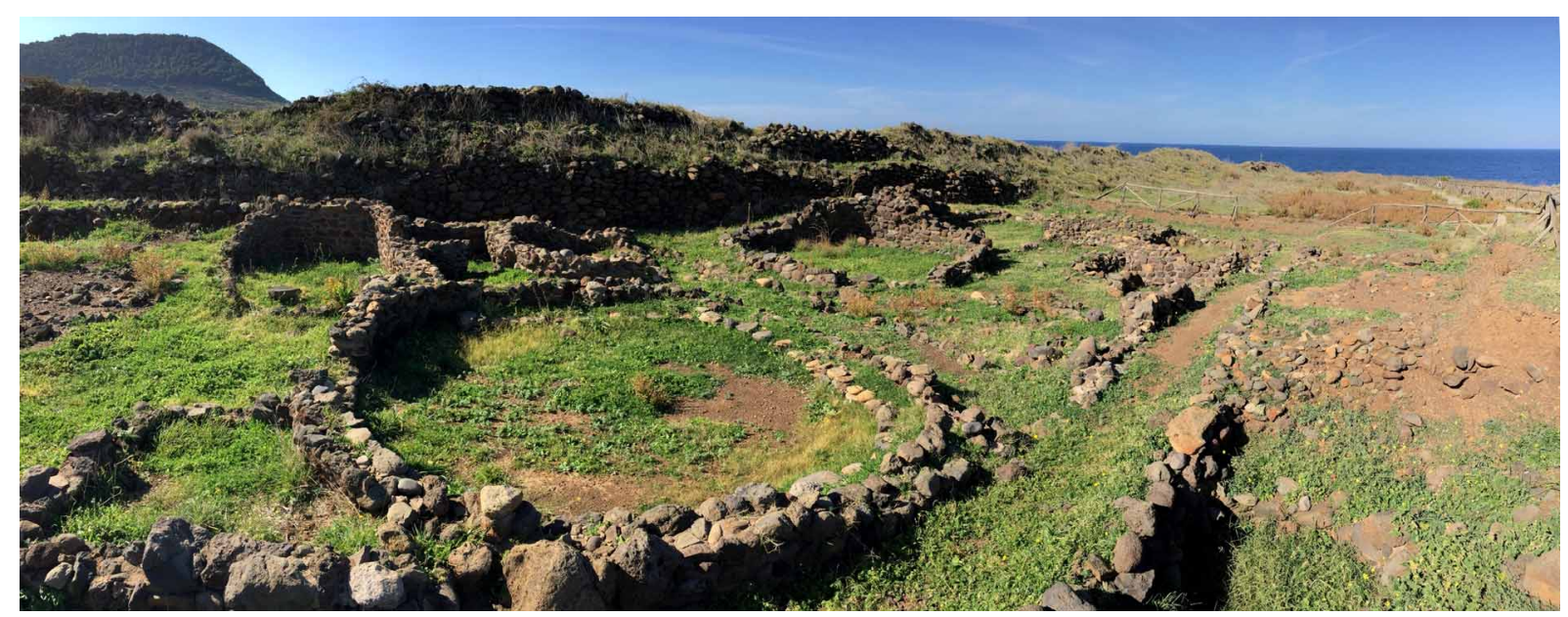

Figure 8. The narrow main street of the Villaggio dei Faraglioni, the bottoms of some huts, and in the background a segment of the defensive wall (Photo by F. Foresta Martin).

The furnishing recovered inside the huts is abundant and well preserved, and a lot of dining and food storage ceramic containers have been unearthed from the floor. Some vases are stylistically identical to the coeval ceramics of the Milazzese Village (Panarea, Aeolian Island), while some others recall the Thapsos Style, consisting of deep truncated cone bowls on high pedestal feet, probably used to consume meals sitting on the ground. The bronze casting activity is attested by five stone molds for the fusion of metal tools recovered inside the village, suggesting the existence of a workshop [Holloway and Lukesh, 1995, 2001; Spatafora and Mannino, 2008].

The excavation campaigns at the Villaggio dei Faraglioni also brought to light a few hundred fragments of obsidian, attesting that the use of this volcanic glass persisted during the Middle Bronze Age, contrary to what is ascertained in other contemporary Sicilian villages, where a decline of these lithic cutting tools is evident [Tykot and Foresta Martin, 2020, and references therein].

The typology of furniture and the organization of living testify that a community devoted to fishing, agriculture, animal husbandry, and craftsmanship inhabited the Village. At the same time, the rational urbanistic plan and the wealth of furnishing of the huts, testify to a well-structured social and economic organization, as well as a high standard of living of the inhabitants [Holloway and Lukesh, 1995, 2001; Spatafora and Mannino, 2008].

The Villaggio dei Faraglioni was inserted into the Mediterranean trade routes: the connection with the contemporary Sicilian culture of Thapsos is self-evident in ceramics [Voza, 1972]. Some long-distance contacts with populations of the continental Greek Bronze Age are attested by a fragment of Mycenaean ceramic and a few necklace beads in glass paste; some sherds with incised decoration in the Apennines style document the participation of the Island in the Tyrrhenian traffic with the Italian peninsula [Holloway and Lukesh, 1995, 2001; Spatafora and Mannino, 2008].

The village was abandoned around $1200 \mathrm{BC}$, when the inhabitants suddenly left, leaving their belongings in their homes. To explain this escape, two main hypotheses were advanced: a natural disaster that induced the population to find a safer place, or a hostile invasion from the sea. But, as we will see later, other hypotheses are plausible. After this dramatic event, Ustica remained uninhabited until the $4^{\text {th }}-3^{\text {rd }}$ century BC, during the Hellenistic-Roman Age, when there is evidence of an intense re-colonization of the island [Spatafora and Mannino, 2008]. 


\section{Franco Foresta Martin et al.}

The relationships between this major Middle Bronze Age settlement and the other contemporary minor settlements existing on the island at Spalmatore, Omo Morto, and Case Vecchie are unknown.

\subsubsection{The Middle Bronze Age Villaggio dell'Omo Morto}

In the bottom of the halved crater of the Falconiera volcano (paragraphs 2.2 and 2.3), during the construction of a water purification plant in 1974, the archaeologist Mannino [1979] recognized the remains of three prehistoric huts with a diameter of about 2.5-3 m each, among which he unearthed fragments of ceramic vases quite similar to those of Middle Bronze Age Villaggio dei Faraglioni. The study of these finds suggests the existence of a small settlement of the Middle Bronze Age, which has been assigned the name of Villaggio dell'Omo Morto, from the homonymous and nearby headland on the eastern coast of Ustica [Mannino and Ailara, 2016], (Figure 9). The construction of the plant almost destroyed this small settlement whose relations with the contemporary Villaggio dei Faraglioni are unknown [Di Stefano and Mannino, 1983; Mannino, 2007a, 2007b; Mannino and Ailara, 2016].

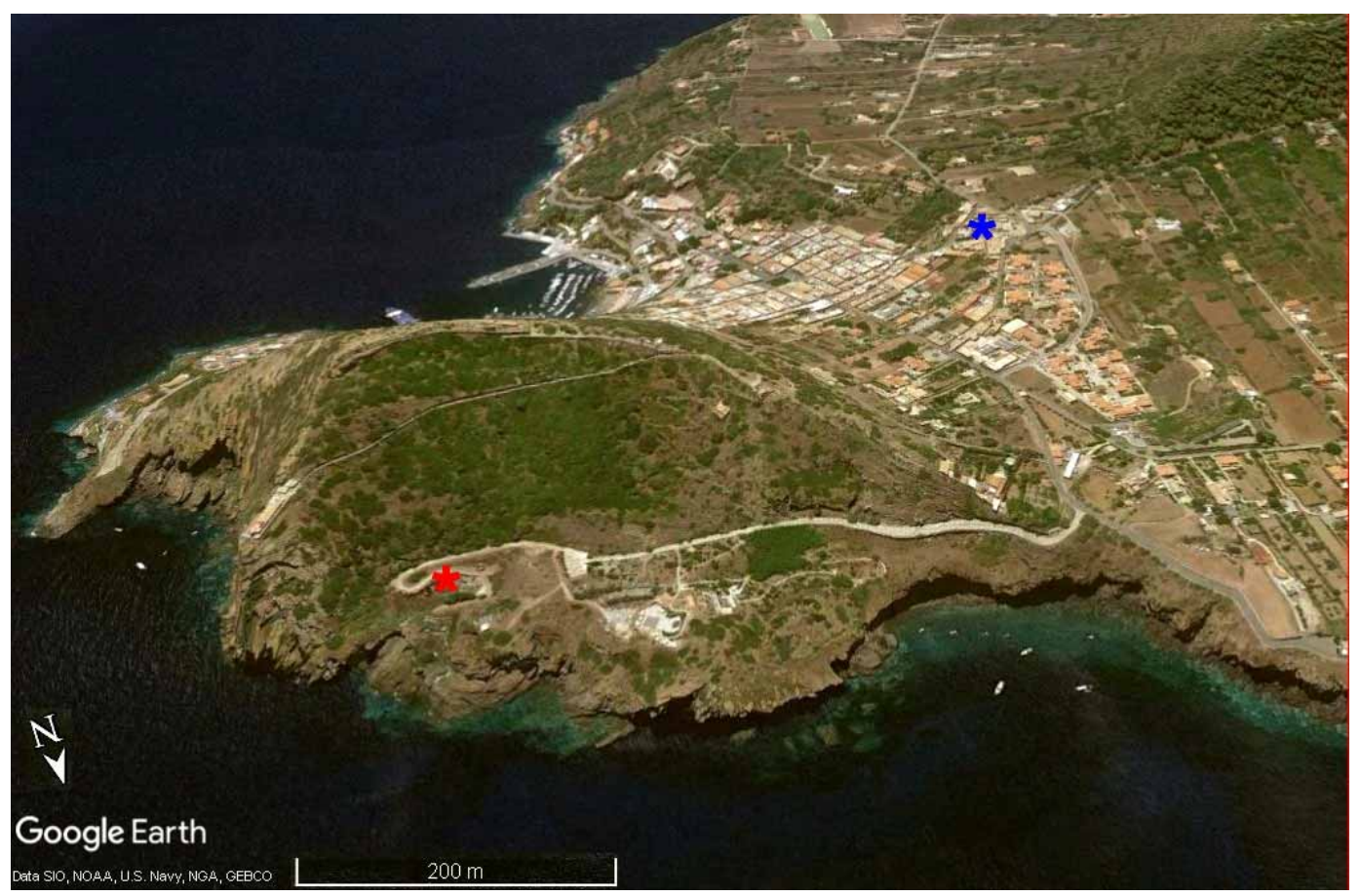

Figure 9. The halved crater of the Falconiera (bottom left) is the place where a small Middle Bronze Age settlement destroyed by the construction of the water purification plant (red asterisc), was located. On the opposite side, there are the Cala S. Maria harbor, the island's main landing place, and the town of Ustica. In the north-western periphery of the town (top right) stands the ancient district of Case Vecchie (blue asterisk). Modified from Google Earth.

\subsubsection{Case Vecchie Middle Bronze Age settlement}

The Case Vecchie district is located on the north-western outskirts of the modern inhabited village of Ustica (Figure 9). Its name, which means ancient houses, was given in the Bourbon period (the mid-1700s) to a group of small houses that had risen around a Cistercian monastery founded around the 13th century AD. The monastery was soon abandoned, like all the other housing of the island, due to the recurrent raids of North African pirates. Probably the Case Vecchie area was inhabited long before the Middle Ages, in prehistoric times, as hypothesized by Mannino [2007a and references therein] following the discovery of ceramic fragments from the Middle Bronze Age and obsidian tools, both in some gardens of the district and in the surrounding agricultural fields. 


\subsubsection{Other relevant places of prehistoric human frequentation}

On the island of Ustica, some places with clear traces of prehistoric frequentation have been identified, although there is not any evidence of human settlements in them. These sites, below listed, probably had stable connections with the human settlements already described and therefore must be taken into consideration to evaluate the relationships between the well-established prehistoric villages and the surrounding territory.

- Grotta Azzurra and Grotta di S. Francesco are two sea caves connected through a tunnel originated by marine erosion, and located a few hundred meters west of Cala S. Maria (Figure 3). In both the caves, abundant fragments of vases dating from the Middle Eneolithic to the Middle Bronze Age, used to collect drinking water dripping from the vaults of the cave, were found. The frequentation of these caves was assiduous in prehistoric times (and even beyond) both for the presence of the water, but also for ritual practices, as suggested by Mannino [1979] and Mannino and Ailara [2016].

- Grotta dell'Omo Morto is a cave positioned a few tens of meters east of the Middle Bronze Age settlement discovered in the bottom of Falconiera crater (paragraph 2.4.5). This cave opens onto an overhanging tuff wall, at an altitude of $30 \mathrm{~m}$ asl, and is very difficult to access due to its position. Inside the cave, fragments of vases from the Middle Bronze Age have been found that suggest a funerary use [Mannino and Ailara, 2016].

- Monte Costa del Fallo, is the second-highest mountain on the island. On the top of the mountain (238 m asl), in 1990, during excavations carried out for the installation of a pylon for radio frequency antennas, ceramic finds dating back to the Middle Bronze Age came to light. Considering the position, which allows the control of the landings on the entire perimeter of the island, the hypothesis has been advanced that in this place was built a sighting post coeval to the Villaggio dei Faraglioni (paragraph 2.4.4), [Mannino and Ailara, 2016].

\section{Methods}

This study aims to associate the geomorphological and some biogeographical characteristics of Ustica island, with the prehistoric settlements so far ascertained by archaeological studies. The purpose of the study is to identify which natural factors may have influenced the choice, duration, and end of human settlements from the Neolithic ( $6000 \mathrm{BC}$ ) to the Bronze Age ( 1200 BC), i.e. during the long period of Prehistory in which the continuous presence of humans is documented in Ustica.

Geomorphological data were collected in the archaeological sites through field surveys conducted by the authors of this paper during the years 2016-2020. Data on sea cliffs were collected following the snorkeling procedures described by Furlani et al. [2017] and Furlani [2020]. Additional data were collected through Unmanned Aerial Vehicles (UAV) surveys. Field data have been uploaded in a geodatabase. Archaeological data have been obtained from the abundant published scientific literature regarding the island of Ustica. The geographical coordinates of the prehistoric settlements and their extent (usually not indicated in archaeological literature regarding Ustica) were collected in the field through GPS surveys and verified through Google Earth Engine (GEE) software. In the case of an archaeological settlement that develops over a large area, the geographical coordinates refer to an estimated midpoint.

The prehistoric settlements object of this study are the following:

- Pirozza and Spalmatore (Neolithic, Eneolithic, Early and Middle Bronze Age), attested by surface collections and shallow test pits;

- Piano dei Cardoni (Neolithic, Eneolithic, Middle Bronze Age), attested by surface collections and a single deep excavation test pit;

- Culunnella (Ancient Bronze Age), attested by surface collections;

- Faraglioni (Middle Bronze Age), attested by various excavation campaigns that have brought to light: bottoms of huts, roads, and fortifications;

- Omo Morto (Middle Bronze Age), attested by collections of finds during the construction of a wastewater purifier.

- Case Vecchie (Middle Bronze Age), attested by surface collections.

We have analyzed some natural factors that could have affected the choice of the site and the everyday life of each of the ascertained prehistoric settlements, through field surveys, Google Earth Engine (GEE) images. Data 


\section{Franco Foresta Martin et al.}

were included in a database built with Microsoft Excel and then imported in QGis 3.16 (Hannover Version) to build georeferenced maps. The final version of the maps were modified with Corel Draw 17.0. The natural factors, that we describe through qualitative analysis, are the following:

- geomorphological characteristics of each site and its near surroundings;

- distance from the sea and altitude of the settlements;

- azimuth amplitude of the visible marine horizon from the site;

- geological unit of belonging and its geochronological dating;

- nearby drinking water resources, their distance, and accessibility;

- contiguous cultivable lands and their areal extension;

- nearby coastal landings, taking into account sea-level variations since prehistoric times;

- nearby coastal areas regarding mollusks collecting and fishing;

- sea caves practicable for collecting dripping water, sheltering boats, cult activities;

- local geological resources that can be exploited for the construction of walls, huts, and stone tools.

We calculated the probability that an island will be colonized, and the colonizers will survive following wellestablished biogeographical principles [see Dawson 2014: 144, 167 and references therein]. For this purpose, a valuation method has been proposed through an island's biogeographic ranking (BGR) index, which can be calculated as follow:

$\mathrm{BGR}=$ IS $(\mathrm{sq} \mathrm{km}) / \mathrm{DNM}(\mathrm{km})$.

Where IS is the island surface, and DNM the distance to the nearest mainland. The higher the BGR, the greater the probability of colonization and survival.

\section{Results and Discussion}

\subsection{Provenances of the first colonizers}

The first contribution that geographic and geomorphological approaches can offer to the study of the prehistoric colonization of Ustica concerns the possible provenances of the first colonizers. Understanding earliest colonization is a classic question in Island Archaeology, a subject that contributes to the knowledge of the past considering also some biogeographical features of the islands [Dawson, 2014 and references therein].

First of all, the probability of the early prehistoric colonization of an island depends on its visibility from the locations where the potential colonizers were initially located, as well as on its distance and therefore on the navigation times needed to reach it [Held, 1989; Patton, 1996]. We have empirically determined an optimal visibility band of Ustica which corresponds to the places on the Sicilian northern coast from which the apparent angular dimensions of the island measured on the horizon line are $>0.5^{\circ}$. We have verified that below $0,5^{\circ}$, even with favorable weather conditions, the island of Ustica fades and doesn't seem an appreciable, reachable target. For comparison purposes, the apparent angular diameter of $0.5^{\circ}$ of an object that stands out in the sky above the horizon line equals that of the Full Moon.

Direct measurements with a bearing compass carried out by us from various sites on the northern coast of Sicily indicate that the optimal visibility of Ustica is limited to a coastal band that goes from Capo San Vito (westward) to Capo Zafferano (eastward), with maximum visibility from Capo Gallo (in between), a big promontory that marks the point of minimum distance $(\sim 55 \mathrm{~km})$ of the northern Sicilian coast from Ustica (Figure 10). At the two extremes of this band, the island extends for about $0.5^{\circ}$, while at the point of minimum distance, it reaches $2.0^{\circ}$. These angular values are lower than those obtainable from a geometric calculation because, due to the Earth curvature and the perspective, from the Sicilian coast at sea level it is possible to see only the highest and shortest profiles of Ustica. Furthermore, it must be considered that the apparent angular dimensions of a distant object visible on the line of the marine horizon, also depend on the variability of the atmospheric refractive index.

Without setting the limit of optimal visibility, the visibility band of the island from Sicily mainland is wider, as it extends westward to the Egadi islands (Levanzo in particular), and eastward to Cefalù; sometimes even up to 
Alicudi, the westernmost of the Aeolian islands. But in these extreme cases, the visibility of the island is sporadic, subordinated to the most favorable weather conditions and to the observers possibility of placing themselves in higher observation points, such as at the top of coastal reliefs. Therefore, the origin of the first colonizers of Ustica should preferably be sought in the prehistoric villages that arose in a large area around the great promontory of Capo Gallo and near Palermo, where the Neolithic cultural horizons have been found, the same attested on Ustica. Of these Sicilian villages that flourished during the Neolithic, detailed surveys have been made by Mannino [1998a; 2015]. Of course, colonizations from more distant villages, located at the extremes of the visibility band, cannot be excluded. But even in this case, considering the difficulties of navigation in the Neolithic Age, very likely the trips to Ustica had the mainland areas closest to the island as a mandatory and intermediate stop.

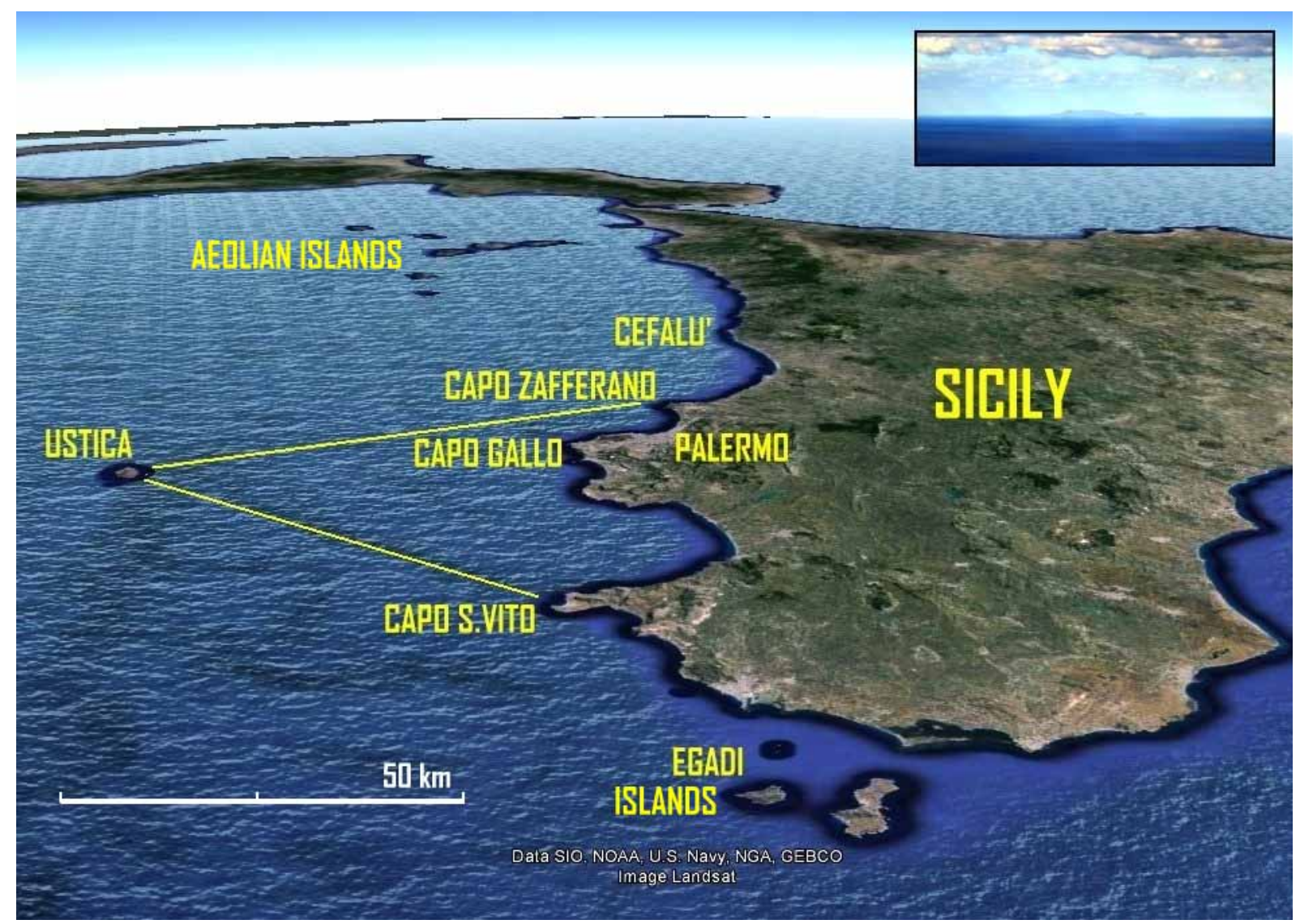

Figure 10. The yellow lines from Ustica intercept on the northern Sicilian coast the places from which there is optimal visibility of the island, which appear on the horizon line at least $0.5^{\circ}$ wide (measurements made at sea level). In the top right insert, the Ustica skyline as you can see from the point of the Sicilian coast closest to the island: the promontory of Capo Gallo. Map modified from Google Earth; the image in the insert is courtesy of Gianmarco Liga.

\subsection{The Neolithic colonizing waves}

Of the thirteen small islands that surround Sicily, ten were colonized already in the Neolithic, including Ustica. For them, we have calculated the BGR index, which albeit with some exceptions is well correlated with their early colonization (Table 3). Lipari, Salina, and Filicudi are the three Sicilian islands at the top of BGR ranking, and they were colonized in the early 6th millennium BC. Ustica occupies fourth place in the BGR ranking, and indeed its colonization occurred a little later.

The colonizing waves were the consequence of the Neolithic revolution: stable settlements, agriculture, domestication of animals, and trade, produced welfare and demographic expansion, requiring the foundation of 


\section{Franco Foresta Martin et al.}

new settlements [Holloway, 1991; Tusa, 2017]. But to explain the widespread Neolithic colonization, some scholars add to the social and economic motivations also the "pioneer ethics" that pushes humans towards the conquest of new territories [Zilhao, 2000; Dawson, 2014].

\begin{tabular}{ccccc} 
ISLAND & $\mathbf{1}^{\text {ST }}$ COL (MILL) & DISTANCE NM (KM) & IS (KM $\left.)^{2}\right)$ & BGR \\
Lipari & 6 & 30.2 & 37.6 & 1,24 \\
\hline Salina & 6 & 42.9 & 26.8 & 0,62 \\
\hline Filicudi & 6 & 46.6 & 9.5 & 0,20 \\
\hline Ustica & 5 & 53 & 8.6 & 0,16 \\
\hline Lampedusa & 5 & 210 & 20.2 & 0,09 \\
\hline Panarea & 5 & 42 & 3.4 & 0,08 \\
\hline Levanzo & 4 & 15 & 7 & 0,46 \\
\hline Favignana & 4 & 17 & 19.4 & 1,14 \\
\hline Marettimo & 4 & 30 & 12.6 & 0,4 \\
\hline Stromboli & 4 & 56.2 & 83 & 0,22 \\
\hline Pantelleria & 3 & 102 & 5.2 & 0,06 \\
\hline Alicudi & 3 & 87.5 & 5.4 & 0,3
\end{tabular}

Table 3. Minor islands of Sicily archaeological and biogeographical data. Abbreviations: 1ST COL (MILL) = Millennium of first colonization; DISTANCE NM (KM) = Distance of nearest mainland in $\mathrm{km}$; IS $\left(\mathrm{KM}^{2}\right)=$ Island size in square kilometers; BGR = Biogeographical ranking of Patton [1996].

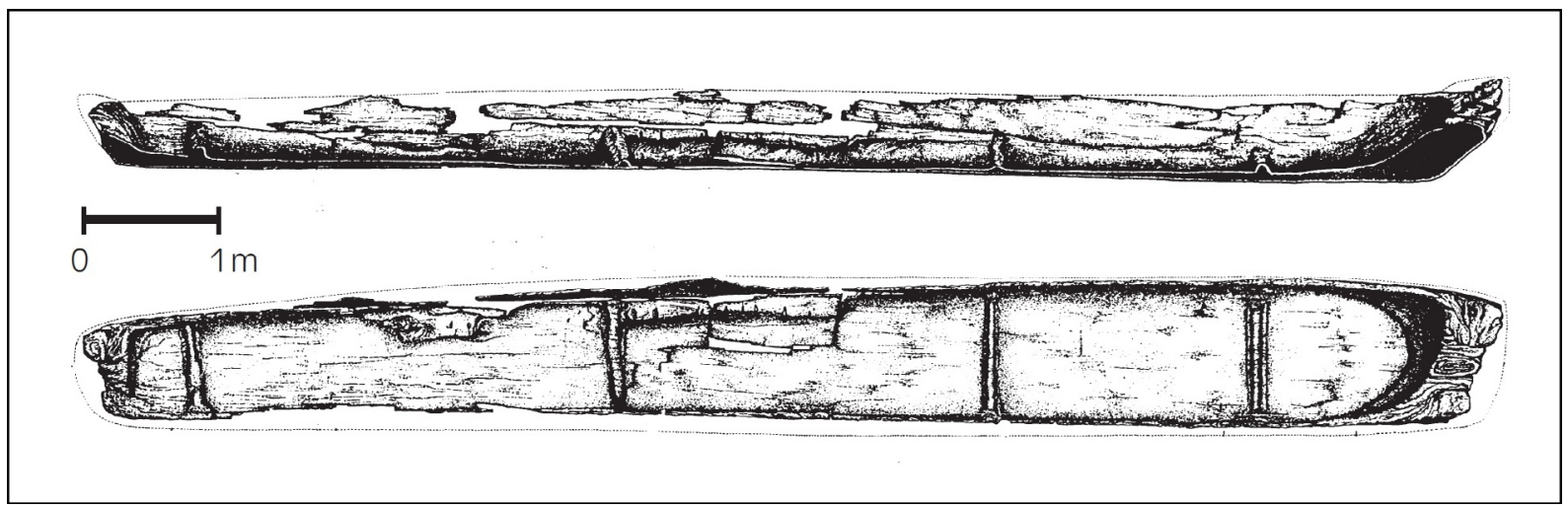

Figure 11. The wreck of the Neolithic pirogue Marmotta recovered from Lago di Bracciano, Italy. Modified from Tichý, 2016.

The first colonization of an uninhabited island like Ustica was an undertaking to be organized with care and to be preceded by preventive explorations. It was necessary to verify that (1) the island had water resources and arable fields, (2) the land and the sea offered animals, mollusks, and fish immediately huntable and edible, (3) the existence of a suitable place to establish a village, (4) the local rocks provided at least part of the materials needed to build houses, stone tools, and ceramic containers. Despite the general lack of water, which we will discuss shortly below, 


\section{Ustica Geomorphology and Ancient Settlements}

Ustica was chosen as an island to be colonized, and was reached by the first settlers between the end of the $6^{\text {th }}$ and the beginning of the $5^{\text {th }}$ millennium B.C., according to the chronological attribution of the impressed and Stentinellian ceramics found at Spalmatore [Mannino, 1998a], (paragraph 2.4.1).

We can imagine that the first settlers moved to the island bringing with them everything they needed to survive, such as stone tools, containers with food, seeds to plant, animals, such as goats and sheep, facing more than one journey from the Palermo coast to the island [Dawson, 2014; Martinelli 2021]. Most likely, the boats used for the crossing were simple vessels, such as monossil pirogues, made from a single log of carved wood, propelled by rowers equipped with paddles, as we can deduce from the discovery of some pirogues wrecks in Neolithic villages [Dawson, 2014; Martinelli, 2021]. One of these Neolithic pirogues, about 10 meters long and $1.20 \mathrm{~m}$ wide, was found in 1994 in the submerged archaeological site of Marmotta (Bracciano Lake, Latium, Italy). The relict was recovered, restored ${ }^{1}$, and dated back to $5450 \mathrm{cal}$ BC with the ${ }^{14} \mathrm{C}$ method [Delpino and Mineo, 1995, Mineo, 2016], (Figure 11).

The Marmotta pirogue was reproduced by the Czech researcher Tichý [2016] who performed some tests of experimental archeology during the 1990s. The replica of the Neolithic pirogue was renamed Monoxylon and used for sea-crossings between Mediterranean islands, including Sicily and the Aeolian Islands, with a crew of four pairs of rowers, a helmsman, and loads of grain and obsidian [ Tichý, 2016; Martinelli, 2021 and references therein]. Thanks to these experiments, it was established that such a boat could travel up to $4 \mathrm{~km} / \mathrm{h}$ in the most favorable sea and weather conditions [ Tichý, 2016]. Taking this figure as a reference value, the shortest route from the Palermo coast to Ustica would have required about 14 hours of navigation, without taking into account possible long stops due to the tiredness of the rowers. A more detailed analysis of the wreck of the Marmotta pirogue showed faint signs of a mast attack on the bottom of the hull and traces of what could be a sail [Delpino and Mineo, 1995]. These clues, if confirmed by further discoveries, would anticipate the use of the first rudimentary sails to the Neolithic, shortening the presumed travel times, on conditions of favorable winds and sea currents. Other indirect data collected in the western Mediterranean area showed that seafaring may have started between 11.5 and 6.4 and ka cal BC, although it probably improved in the Neolithic [Lo Presti et al., 2019]

\subsection{No water, no colonization}

The first colonization of Ustica represents a challenge to the common belief that where the shortage of drinking water dominates, the life of a community cannot be established and prosper. The scarcity of a vital resource such as water in Ustica depends on its hydrogeological and geomorphological features. The geological arrangement of the island, characterized by an intricate system of faults, underground cavities, and tunnels that follow the ancient magmatic conduits, prevents the formation of a permanent surface hydrographic network and underground aquifers [de Vita, 1993]: therefore the island has always lacked natural resources of drinking water, nowadays provided by a seawater desalination plant.

Despite the connate lack of underground spring water, the first prehistoric communities living in Ustica were able to survive and develop thanks to two methods of water supplying: (1) the collection of water dripping from the vaults of sea caves, such as the Grotta Azzurra and Grotta San Francesco, and (2) the collection of water during rainy periods. Both of these resources were random, since the first, although more regularly distributed over time, depends on the second. Prolonged periods of drought, in fact, drastically reduce the daily flow of dripping water. But if we consider that prehistory, up to the Middle Bronze Age, was a long period of constant human presence on the island of Ustica [Spatafora and Mannino, 2008], we must deduce that the few resources of water captured and stored up were enough to satisfy the needs of small communities, or tentatively that rainfall was on average higher than nowadays.

Our field surveys, integrated with historical literature, allow us to identify at least five sites, easily accessible also from land, where is possible to collect 50-100 liters of dripping water per day: Grotta Azzurra and Grotta di San Francesco (two contiguous and communicating sea caves on the south-eastern coast); Grotta Pirciata (a sea cave on the border between Arso and Spalmatore, in the south-western coast); Grotta della Fossa (an inland cave, $50 \mathrm{~m}$ a.s.l., in Spalmatore); Falconiera Tuff-Layers of Cala S.Maria, that absorb and release rainwater through the stratified pyroclastic deposits [Pigonati, 1762; Calcara, 1842; Russo, 1875; D’Asburgo, 1898; Mannino and

\footnotetext{
1 The wreck of the Marmotta pirogue is on display at the Luigi Pigorini Ethnographic Prehistoric Museum in Rome, Italy.
} 


\section{Franco Foresta Martin et al.}

Ailara, 2014], (Figure 3). There are some other sea caves, today accessible only from the sea, with few amount of dripping water, but probably during the Neolithic Age, they could be easily accessed. According to the most recent studies of Anzidei et al. [2014], and Benjamin et al. [2017], the sea level in the Neolithic Age was about 20 meters lower than today. This resulted in a wider island area, especially in the parts of the island characterized by lowlying coasts (Figure 12), and in the possibility of accessing a greater number of caves with dripping water directly from inland.

Although the tourist frequentation of some water dripping caves and the creation of access paths have altered some parts of their basement (e.g. Grotta di S. Francesco and Grotta Pirciata), it can be seen that the dripping water has carved natural basins on the rocks, where the accumulating liquid could have been collected. The prehistoric communities drew from these natural reservoirs of freshwater and supplemented the collection by placing vessels under the dripping points, as proved by the discovery of ceramic fragments of various ages inside the caves (paragraph 2.4.7).

Nowadays we can estimate that the most easily accessible dripping water in caves can provide a total of 250-500 liters of water per day. Assuming that the first Neolithic colonizers of Ustica could rely on a comparable quantity of water, and fixing the minimum survival requirement of a human being at 2.5 liters of water per day [Reed and Reed, 2013], we can deduce that dripping water resources alone could support a community of between 100 and 200 individuals, even before more advanced systems for collecting rainwater were organized.

\subsection{The two faces of the Neolithic colonization}

For a long time after the discovery of Neolithic remains at Pirozza [Mannino, 1998a] it was believed that this hill in Spalmatore district (where abundant fragments of pottery attributable to various Neolithic stiles have been found - see paragraph 2.4.1, Figures 4 and 5), was the only human Neolithic settlement in the island. But a recent discovery has revealed the existence of another Neolithic settlement at Piano dei Cardoni [Speciale et al, 2020; Speciale et al., 2021a,b]. One of the most intriguing aspects of these two Neolithic settlements concerns their different geomorphological characteristics: the first is perched on the top of a hill facing the sea that looks naturally fortified (paragraph 2.4.1, Figure 4); while the second is located in a vast and open plain gently sloping down to the sea (paragraph 2.4.2, Figure 6), therefore exposed to potential attack from all sides.

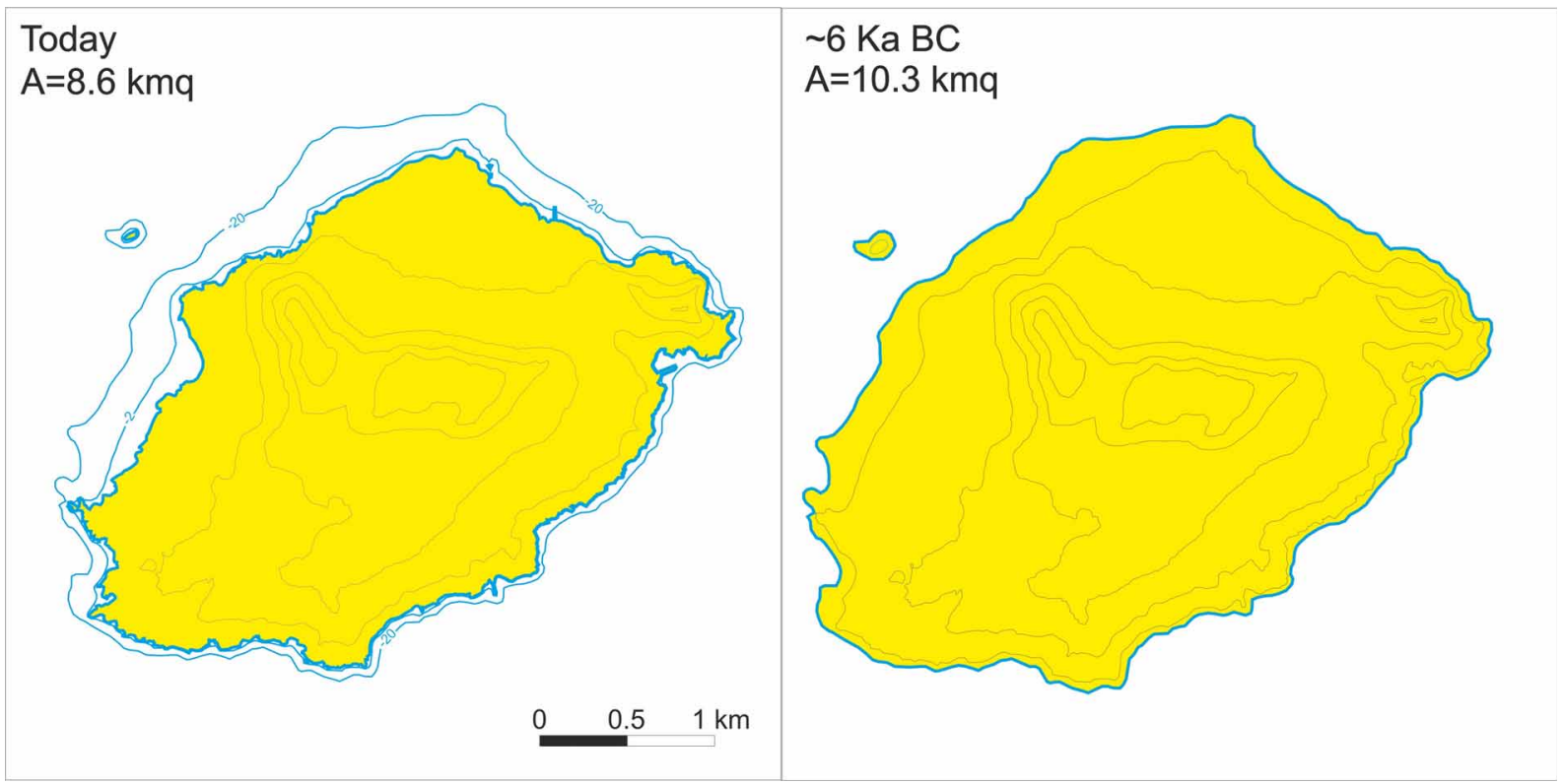

Figure 12. Comparison between the surface of the island of Ustica today $\left(8.6 \mathrm{~km}^{2}\right)$ and during the Neolithic Age (10.3 $\mathrm{km}^{2}$ ), bearing in mind that the sea level was about $20 \mathrm{~m}$ lower (Furlani, this work). 


\section{Ustica Geomorphology and Ancient Settlements}

\subsubsection{The Pirozza natural fortress}

The Pirozza hill $38.696710^{\circ} \mathrm{N}, 13.157273^{\circ} \mathrm{E}, 50 \mathrm{~m}$ a.s.l. at the top, is located in the context of subaerial lava flows with a trachi-basaltic composition, that erupted $\sim 300 \mathrm{ka}$ BP and consolidated forming marked columnar jointing [de Vita, 1993]. Towards the sea, westward and southward, the sides of the hill are surrounded by almost vertical columnar basalts which give it the appearance of a fortress. On the opposite side, eastward, the top of the hill joins the lower altitudes of the hinterland through a steep slope. On this side, the easiest access to the top of the hill is a narrow path, surely existing since the Neolithic.

The top of the hill looks like a well-leveled horizontal plateau, rhomboid-shaped, with an area of about 1600 square meters. This carefully leveled platform, atypical in a rugged volcanic context, has been attributed to the work of the Neolithic humans, which would have chosen it as the site of the first inhabited area of Ustica, further making it safe with surrounding stone walls [Mannino, 1998a]. Even if human works are evident, it must be considered that the first leveling of the hill's top was natural, carried out by a marine transgression of the Crotonian age (Marine Isotope Stage 7, MIS 7) that about $240 \mathrm{ka}$ BP created the terraced surfaces of Ustica Island, today lying between 40-60 $\mathrm{m}$ a.s.l. (Table 1), [de Vita and Orsi, 1994].

In choosing Pirozza as the site of a small Neolithic village, the need for defense against possible hostile attacks is evident. The steep slopes of the hill made the village defensible on almost all sides, and a moat, or a wall, had to defend the only easily accessible narrow path on the eastern side. The arc of the marine horizon visible for people living on the top of the hill was wide, about $220^{\circ}$, from SSE to NNE. The remainder of the azimuth arc, however, is covered by the mountainous reliefs, and, importantly, the hidden part includes some easy landings on the island along the north and southeast coasts. Consequently, an effective defense would have required look-out points on the island's highest peaks, Monte Guardia dei Turchi and Monte Costa del Fallo. Of a possible wider defensive system already existing during the Neolithic, we have only faint clues (paragraph 2.4.7).

The Neolithic settlement of Pirozza represented a well-considered choice not only for the safety of its inhabitants but also for what we could define as the strategy of survival. At the foot of the hill, on its northern and eastern slopes, at altitudes ranging between 30 and $40 \mathrm{~m}$ a.s.l., an area of about 5 hectares $\left(50,000 \mathrm{~m}^{2}\right)$ extends. It consists of terraced surfaces leveled during the MIS 5.5 Thyrrenian transgression, about $130 \mathrm{ka} \mathrm{BP}$. This area, now occupied by the bungalows of a tourist resort, is made of excellent quality fertile soil, exploited during the past millennia for various types of agricultural production.

The supply of dripping water was guaranteed by two nearby sea caves, the Grotta Pirciata, which is located just $350 \mathrm{~m}$ south of the Pirozza hill, and the Grotta della Fossa, about 800 meters toward the northeast; each of them was able to supply 50 to 100 liters of water per day. But to supplement the stillicide water, the small Neolithic village of Pirozza must have provided a system of wells and ceramic pithoi for collecting rainwater. Most likely the dripping water caves represented ideal places, as well as for utilitarian purposes, also for worship practices, as hypothesised by Whitehouse [2016], dedicated to the cult of water that dripped from the white stalactites, possibly symbolizing milk from the mother's breast.

Also, the geomorphological characteristics of the coast were favorable to the prosperity of the Pirozza Neolithic village. The inhabitants had easy access to the sea, being at about $150 \mathrm{~m}$ from the lowest coasts of the island. Moreover, we have to consider that in the 5th millennium BC the sea level was lower, and the coastal strip wider than today (Figure 12). At Spalmatore the coast is formed by very indented sea cliffs, with several small bays and coves, and reliable for the collection of edible shellfish and fishing, as well as for the storage of small boats. Along this low coastal stretch, several sea pools with stagnant seawater occur, wherein seawater evaporation generates edible salt of good quality. All these propitious geomorphological conditions contributed to the fortune of this settlement which, as attested by the archeological finds, had a long life expanding in the neighboring lands, and continuing in subsequent epochs (paragraph 2.4.1).

\subsubsection{Piano dei Cardoni open access settlement}

Piano dei Cardoni is a district on the south-eastern side of Ustica that extends from the outskirts of the inhabited center (Case Vecchie) to San Paolo-Oliastrello districts (Figures 2 and 3). It occupies a portion of about $0.5 \mathrm{~km}^{2}$ of a vast marine terrace that covers the southern sector of the island. From the geomorphological point 


\section{Franco Foresta Martin et al.}

of view, Piano dei Cardoni is a plain gently sloping towards the sea. The bedrock of Piano dei Cardoni is formed by the basaltic lava that flowed from the first emerged volcano, Monte Guardia dei Turchi, which has the main crater in the highest point of the island, $248 \mathrm{~m}$. a.s.l., and a secondary crater int the Culunnella hill, $238 \mathrm{~m}$. a.s.l. This volcano had a predominantly effusive style and its lavas poured from the eruptive vents down to the sea, forming flows that can be seen emerging in some areas from the blanket of the agricultural land (Figure 2).

An elevation profile, from the sea to the top of Monte Guardia dei Turchi, passing through Piano dei Cardoni, shows an evident tripartite division of the slopes. In the coastal zone, from 0 to $80 \mathrm{~m}$ a.s.l. the slope is steep, with an average gradient of $25 \%$; in the intermediate zone, from 80 to $120 \mathrm{~m}$ a.s.l. the slope is moderate with an average gradient of $7 \%$; in the highest zone, from 120 to $248 \mathrm{~m}$ a.s.l. the slope becomes steep again, with an average gradient of $20 \%$. The intermediate zone corresponds to a marine terrace that eroded, leveled, and covered the lava flows with sediments, reducing their original slope (Figure 3). According to the absolute dating $\left({ }^{230} \mathrm{Th}\right.$ method) made on carbonate deposits associated with this terrace, its formation age is $\sim 350 \mathrm{ka}$ BP [de Vita e Orsi, 1994]. It, therefore, represents the oldest marine terrace (1st order, Table I) of Ustica.

The soils of the terrace consist of debris partly marine and partly continental, whose thickness varies from $<1$ to $10 \mathrm{~m}$. On it, several rounded boulders deriving from blocks of basaltic lava lie. In more recent centuries, the peasants have used the boulders to mark the boundaries of the properties.

In this geomorphological context, in the 80s of the last century, an archaeological survey carried out by Mannino [1991] through an area of a few tens of $\mathrm{m}^{2}$ centered on the coordinates $38.705483^{\circ} \mathrm{N}$ and $13.1893^{\circ} \mathrm{E}$, $90 \mathrm{~m}$ a.s.l., led to the discovery of abundant ceramic finds referable to the Eneolithic and the Middle Bronze Age [Mannino, 1991]. Afterward, in the years 2018-2020, in area $\sim 100 \mathrm{~m}$ northeast, with coordinates $38.7062472^{\circ} \mathrm{N}$ and $13.1888138^{\circ} \mathrm{E}, 102 \mathrm{~m}$ asl, some excavation tests attested to the presence of middle Neolithic ceramics, outlining the layout of a settlement rich in evidence of daily material life: stone tools, millstones, mortars, pestles, bones of domestic animals [Speciale et al, 2020; Speciale et al., 2021a,b], (paragraph 2.4.2). Although the analysis of the abundant finds is still in progress, the evidence found here confirms that this part of the island was also selected for settlement, with prehistoric villages extending into the Neolithic to the Eneolithic periods and later.

The geomorphological and biogeographical characteristics of Piano dei Cardoni markedly differ from those of the Neolithic site of Pirozza at Spalmatore described in the previous paragraph. The sea is far from the Piano dei Cardoni settlement, about 600 meters to the east, and the steep coast makes it difficult to access. The fishing and collection of edible mollusks, such as limpets, cockles, snails, sea urchins, that abound on the coasts of Ustica, would have required to move even further east, in a more easily practicable bay such as Cala Santa Maria. There, it would have been possible to draw small boats ashore too. In the same area, there were the major resources of dripping water, from Grotta Azzurra and Grotta di S. Francesco caves, and from tuff layers of the Falconiera, which ensured a few hundred liters of water per day. A continuous movement and transport of people and resources from the village to the coastal area of Cala Santa Maria and vice-versa was therefore necessary.

The site of Piano dei Cardoni seems to indicate an agricultural-pastoral vocation of its inhabitants rather than a marine one. The area offered several hectares of fertile soils with a favorable midday sun exposure and the proximity to the heights of Monte Guardia dei Turchi which at that time had to be covered by a forest of evergreen trees and bushes, sources of precious firewood. Indeed, recent archaeobotanical studies have highlited the presence of holm oaks and pine trees in the mid- $5^{\text {th }}$ millennium, subsequently canceled by the impact of the first human communities on the environment of Ustica [Speciale et al., 2021c]. Intense use of some local mineral resources is also emerging from the archaeological excavation at Piano dei Cardoni: mortars, pestles, axes, and millstones are made with the basaltic lavas of Monte Guardia dei Turchi; abrasive stones with pumice from Grotte del Lapillo or Oliastrello deposits [Speciale et al., 2021a,b].

The settlement of Piano dei Cardoni, however, seems exempt from the defensive concerns that dominated the Neolithic village of Pirozza in Spalmatore. On the contrary, it could be defined as an open-access village, exposed on all sides to possible attacks, unless we hypothesize the existence of defensive works as surrounding walls and moats whose traces have been destroyed by the intense agricultural use of the land in the recent centuries, and which should emerge in the course of deeper archaeological excavations. 


\section{Ustica Geomorphology and Ancient Settlements}

\subsubsection{Who came first?}

The early colonizers of Ustica whose settlements have so far been ascertained in two different places of the island, Pirozza hill on the western side and Piano dei Cardoni on the south, from a chronological point of view seem to belong to the same period: the Middle Neolithic Age. The question arises: which of the two settlements is the earlier one? The archaeological finds analyzed so far do not provide a conclusive answer. In the case of Pirozza, no archaeological excavations have been carried out on the site, and the surface finds, although abundant and diagnostic, provide an incomplete chronological picture. Furthermore, no geochronological analyses have been carried out on the impressed Neolithic ceramics that mark the oldest phase of this settlement, which would allow us to obtain an absolute dating. In the case of Piano dei Cardoni, much of the material collected during the first excavations are still to be analyzed. However, five geochronological datings have been made on ceramic impressed finds that constitute the oldest horizon found so far for this site, and the results (non yet published) indicate the first half of the 5th millennium BC [Speciale et al., 2021a,b]. The full comparison between the ages of the two sites can only be carried out in the future when there will be sufficient analysis to establish a reliable chronological succession of the materials recovered.

Meanwhile, the geomorphological characteristics of the two sites allow us to put forward some hypotheses. We may suppose that the first coming of Neolithic colonizer on an island never inhabited before, led to choose a small place perched and well defensible such as the Pirozza hill, enough to accommodate and protect the early group of inhabitants. In a second phase, after having mastered the island, and verified the absence of threats, can be explained the choice of a larger and more open area such as Piano dei Cardoni, whose inhabitants could be constituted by a new wave of colonizers coming from the Sicilian mainland or, less probably, by the expansion of the first settlers. It should be remembered that the latter had already as a privileged area of expansion the lower-level land of Spalmatore, where the tourist resort stands today and where surface finds attributable to the periods following the Neolithic have been found. But a simultaneous arrival of two different groups of Neolithic colonizers cannot be excluded. In this case, the choice of two sites as different as Pirozza and Piano dei Cardoni depends on the different way the two groups faced the problems of survival and confrontation with their peers.

\subsection{The Early Bronze Age Castling}

The Early Bronze Age, judging by the only example of human settlement of this period identified so far at Ustica, records an abrupt change compared to the previous Eneolithic period. The inhabitants moved from the open-access settlement of Piano dei Cardoni to the top of a steep hill 600 meters to the north: the Culunnella. Its coordinates referred to the center of the summit are $38.707516^{\circ} \mathrm{N}, 13.182215^{\circ} \mathrm{E}, 238 \mathrm{~m}$ a.s.l. The Village built up there expresses the need for extreme defense and control of the landing sites at Ustica from above. The Culunnella is the secondhighest peak of the island, from which you can have a $360^{\circ}$ view of the entire coastline. By choosing a site from which it was possible to monitor the sea and, at the same time, to keep away from it, Ustican people manifested the fear of the increasing piracy that already in the Early Bronze Age concerned the Mediterranean islands and coastal locations. Pirates came unexpectedly, raiding the villages and sowing death, as a consequence of the flourishing of maritime trade and the exchange of exotic and precious goods between distant peoples [Tusa, 2017: 234].

According to Mannino [1991] the summit of Culunnella was leveled by people of the Early Bronze period, who created a $2000 \mathrm{~m}^{2}$ wide platform, surrounded by boulders, and capable of hosting a small village made up of a dozen huts. The extent of the settlement has not been ascertained by excavations but can be inferred from (1) the analysis of ceramic and tools finds collected on the surface (facies of Capo Graziano), (2) the layout of the defensive boulders, and (3) the nearby presence of a necropolis with rock-cut tombs [Mannino, 1991, 2008], (paragraph 2.4.3).

The Culunnella hill is the relic of a secondary crater of Monte Guardia dei Turchi, whose volcanic form has been completely lost. A stratigraphic section of this area shows at the cliff toe the lavas of Monte Guardia dei Turchi, on which are superimposed the tuffs of Monte Costa del Fallo, and the ashes of Grotte del Lapillo. This extremely varied and available in situ lithology, represented an advantage for the inhabitants of the village, who were able to exploit it for the construction of the huts, the lithic tools, and the necropolis. The water supply must have been problematic, given the absence of dripping caves in the surroundings and the need to transport it from the springs near Cala $\mathrm{S}$. Maria (paragraph 4.4.2), except for rainwater collected on-site. 


\section{Franco Foresta Martin et al.}

On the northern side of the Culunnella hill, a few meters below the archaeological settlement, there are some vuccaroli that for sure attracted the attention of the Early Bronze Age settlers. With this local dialectal term, the Ustica people of the 19th century indicated underground cavities from which, intermittently, hot air comes out, sometimes so full of water vapor as to be mistaken for smoke, and to cause fear of the awakening of the ancient volcano [Martinelli, 1910]. On the occasion of a long sequence of small-medium earthquakes that occurred in Ustica in March-April 1906, geologists of the University of Palermo ascertained that the emission of vapors from vuccaroli was caused by the circulation of hot-humid air within the system of ancient ducts of the extinct volcanic systems and that it was not an omen of its reactivation [Martinelli, 1910; Mannino, 1998b]. Geochemical analyzes on vapor flow carried out by Foresta Martin and Nuccio in 1998, identified the presence of magmatic helium, a gas of deep volcanic origin attesting to the persistence of degassing in a system whose activity has been extinct for over 100 thousand years [Foresta Martin, 2001]. Testimonies collected from the island's elder people report that up to the beginning of the 20th century, on cold winter days it was the custom of farmers and shepherds who worked near the Culunnella hill, to go and warm up next to the vuccaroli [Foresta Martin, 2001]. It is easy to think that prehistoric men also did the same. The steam flows from the vuccaroli have significantly decreased in the last decade.

Given the strategic position of the Culunnella, it is likely that the site could be occupied both before and after the Early Bronze Age as a lookout point, in favor of the villages located at lower altitudes, where the horizon is partially obscured by the surrounding hills.

\subsection{The Middle Bronze Age Village overhanging the sea}

The Middle Bronze Age witnessed the development of one of the best-preserved Mediterranean sites of that period, the so-called Villaggio dei Faraglioni, (paragraph 2.4.4). The remains of the village occupy about $7000 \mathrm{sq} \mathrm{m}$ of a terrace placed on the edge of a high cliff in the northernmost tip of the island, centered on coordinates $38.718972^{\circ} \mathrm{N}, 13.182170^{\circ}$ E, $18 \mathrm{~m}$ a.s.l. Some bottoms of huts and archaeological finds have been found also on the top of the Colombaio, a stack located about $60 \mathrm{~m}$ north from the coast (Figure 7), [Mannino, 1970; 1979; Spatafora and Mannino, 2008].

The geological nature of the site has condemned this prehistoric settlement to a slow dismantling. It is located on a Tyrrhenian marine terrace (Tab. I) that lies above two ancient ( $320 \mathrm{ka} \mathrm{BP})$ volcanic formations, the Gorgo Salato and the Tramontana lavas, both consisting of columnar lavas marked by vertical and horizontal deep cracks. Furthermore, this stretch of coast was cut by an NW-SE-oriented fault. As a result, the high cliff is subject to repeated collapses, mostly due to the mechanical action of the sea waves which erodes it at the base and covers it entirely during the frequent winter storms.

The reconstruction of the palaeomorphology was made by Furlani and Foresta Martin, [2019] using archaeological and geomorphological data. Archaeologists point out that the presence of archaeological finds on the sea edge of the terrace and the top of the Colombaio stack suggest that there was a connection between the stack and the mainland. Mannino [1970,1979] proposes that in the Middle Bronze Age the village extended over an area of about $14.000 \mathrm{sq}$ m, i.e. double compared to the current one, incorporating the Colombaio stack. Spatafora [2005, 2009] supports the idea that there was at least a natural bridge suspended on the sea between the stack and the coast. In both cases, the connection would have collapsed following a natural catastrophic event such as a strong earthquake which prompted the villagers to leave the area for good.

Furlani and Foresta Martin, [2019] observe that the collapse of a terraced surface double compared to the current one, if it occurred in the Middle Bronze Age, would have left a residue of material much more consistent than that nowadays emerging from the sea between the cliff and the stack. Likely, the retreat of the coast and the reduction of the Tyrrhenian terrace took place in much longer geological times. More compatible with the volumes of the emerging materials detectable today is the hypothesis of the collapse of a narrow bridge, stretching across the coast and the stack. But even this is not strictly necessary to explain the human activity on the top of the stack because during the Middle Bronze Age the sea level was lower than today and therefore the stack was naturally connected to the mainland through a path slightly emerging from the sea. The maximum depth measured nowadays in the channel separating the stack from the mainland is $-2 \mathrm{~m}$ a.s.l. Considering that the sea level in the Middle Bronze Age was about $2.5 \mathrm{~m}$ lower than today, as suggested by Furlani et al. [2017], it is likely that a small path of rock emerged few centimeters above the sea level and connected the foot of the sea cliffs with the stack. Today's morphology is mainly governed by coastal processes that act during the strongest storms on sea cliffs. Moreover, 
sea cliffs are often subject to collapses due to landslides. Slab failure occurs mainly by toppling or rock falls. As a consequence of cliff retreat, a shore platform develops at the cliff toe. According to Kuhn and Shepard [1984], the presence of humans could also have altered the normal erosion of the cliff-platform system.

An example of the slow formation of a stack quite similar to the Colombaio can be observed if you place yourself in the eastern corner of the archaeological village, looking towards the coast. From there, you will be able to see a block of the high cliff crossed by an almost vertical dike (Figure 13). The dike, which acts as an element of structural discontinuity, is already eroded at the foot of the cliff by the action of the sea, and when it will collapse, the cliff block will detach itself from the rest of the coast. Then, the slow retreat of the cliff will make it become the third stack of this remarkable landscape where geomorphology and archaeology merged and evolved together.

Regarding the hypothesis of a strong earthquake, if it occurred in the Middle Bronze Age, and had been the cause of the collapse of part of the village to the sea, it would have left discernible signs of breakings and disruptions also on the long and tall defensive wall, which instead is substantially intact, except for some anthropogenic dismantling actions caused by the collection of the boulders as a building material in the last century, when the archaeological value of this site was still unknown (Figure 14).

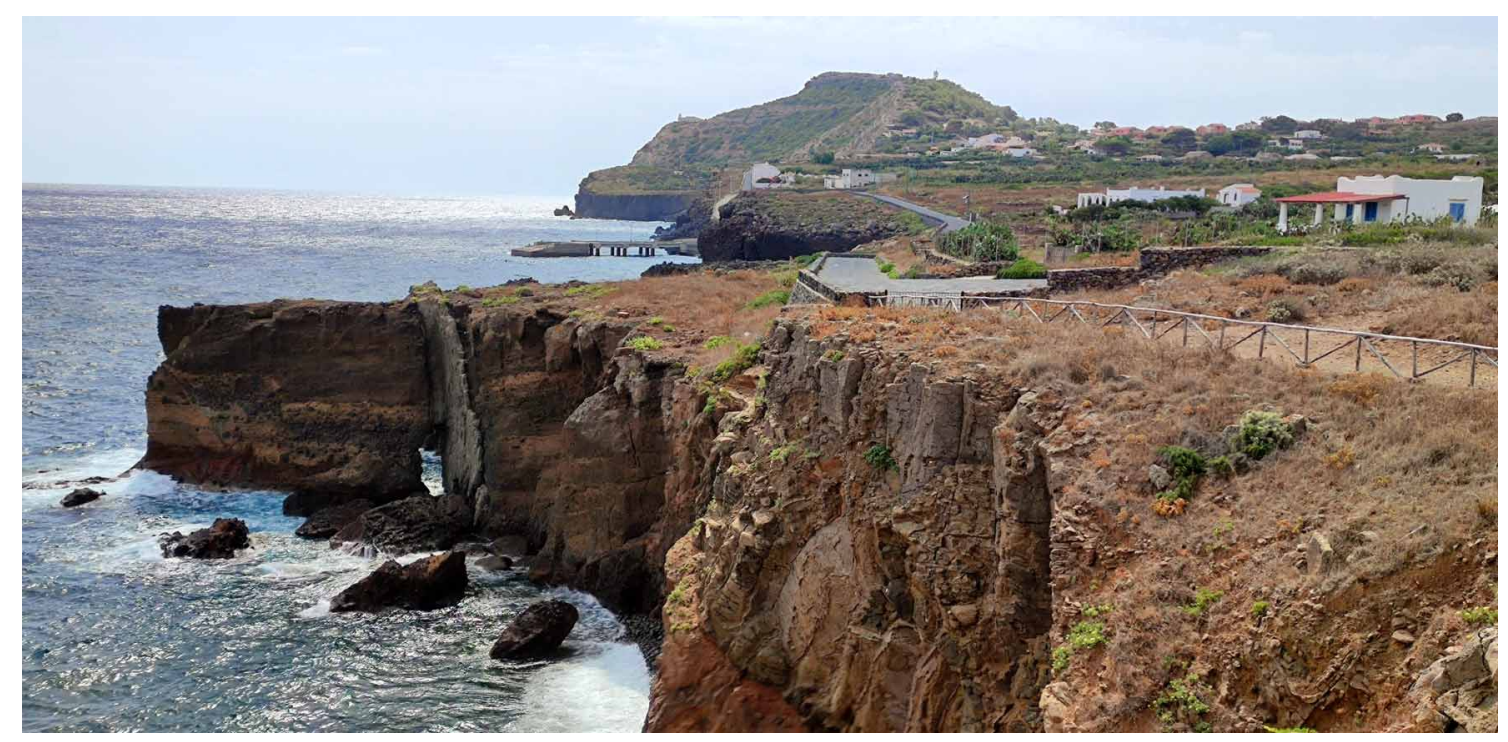

Figure 13. A block of the cliff crossed by a vertical dike shows the premise to the formation of a stack, at the eastern corner of the Villaggio dei Faraglioni (Photo by Foresta Martin).

One of the reasons for the choice of this place by Middle Bronze Age settlers can be related to its topographical and morphological characteristics, which seaward offers a natural protection thanks to the high cliffs. Landward the defense was entrusted to the mighty arched wall, about $250 \mathrm{~m}$ long and over $4 \mathrm{~m}$ high, reinforced by thirteen buttresses, which surrounds the whole area of the village (Figure 14). The building blocks of the defense wall are made of rounded boulders whose diameter varies from 0.20 to $1 \mathrm{~m}$, belonging to the local lava units of Gorgo Salato and Tramontana. The presence of a mighty fortified wall raises some questions: was it used to defend the village against foreign enemies coming from the sea, or also from other groups inside the island? Were the other Middle Bronze Age settlements scattered throughout the small territory of Ustica satellites of the Villaggio dei Faraglioni - which so far seems to be the most evolved and organized settlement on the island - or rather antagonists? Future excavation will help clarify these questions. The visibility of the marine horizon from the Villaggio dei Faraglioni was wide but limited to about $180^{\circ}$ from WNW to ESE. The entire southern horizon of the island, the one that looks to nearby Sicily, remained obscured by the reliefs. For this reason, it is necessary to think of the existence of one or more sighting posts on the highest peaks of Ustica capable of communicating with the village with fires or other visual and acoustic signals. 


\section{Franco Foresta Martin et al.}

The choice of the place denotes a partly seafaring and partly agricultural vocation of its inhabitants. The sea was easily accessible, beyond the defensive wall, on the western side, where the cliff is less high and there are numerous bays and inlets ideal for fishing and the storage of small boats. Landward, outside the walls, the vast agricultural fields of the Tramontana plain ensured much of the food needs for the small community. The presence inside the village of numerous millstones obtained from basaltic, hawaiitic, and mugearitic lavas with alkaline-sodium affinity typical of Ustica volcanism [Santi et al., 2020], testifies to the production of flours obtained from the cultivation of wheat and cereals. The drinking water had to be mainly ensured by the collection of rain in wells and pithoi placed next to the huts of the village [Holloway and Lukesh, 1995, 2001]; the nearest sources of dripping water were about $2 \mathrm{~km}$ away, in the Cala S. Maria area. But we must also consider that about 500 meters west of the village there are the stagnant waters of Gorgo Salato: a mixture of rainwater and marine aerosols that are naturally collected in the basins formed by the homonymous lavas. Even if it is slightly brackish water, the mini-lakes of Gorgo Salato have been exploited over the millennia, both for the irrigation of agricultural fields and for the watering of animal farms [Mannino and Ailara, 2016]. In the same place, the silt enriched with minerals deriving from the alteration processes of the Gorgo Salato lavas (onion-like desquamation) may have provided clay for the production of pottery, which could be easily confirmed by future petrographic analyses of the ceramics.

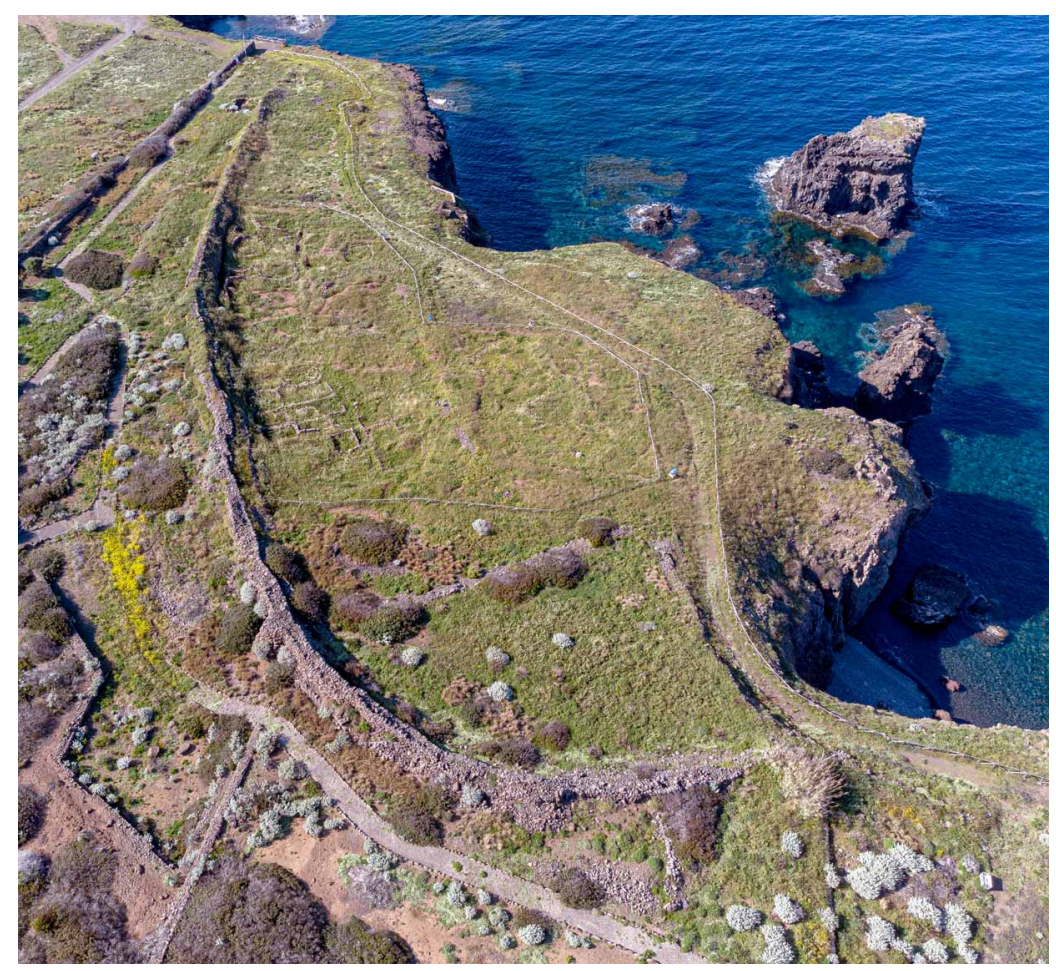

Figure 14. Drone view of the Middle Bronze Age Villaggio dei Faraglioni, with the long (250 m) and arched defensive wall (Drone photo by Stefano Furlani).

In contrast to all the listed advantages, it must be added that the site is among the most unsuitable on the island to establish a permanently inhabited village. In winter it is exposed to the harsh winter winds and the marine aerosol; in summer, it is dominated by the heat, not tempered by the presence of trees that couldn't take root there due to the high saltiness levels. In an attempt to explain the choice of this site so projected towards the sea and hyper-defended towards the land, Holloway and Lukesh [1995: 8] imagined the Villaggio dei Faraglioni as a fortress inhabited by pirates, who lit fires on the top of the Colombaio Faraglione to attract passing boats and capture them. But this interpretation has been rejected by other scholars [Leighton, 2004].

The Villaggio dei Faraglioni has also been the subject of archaeoastronomical studies by Foresta Martin and Magli [2016], which have highlighted its peculiar position relating to the winter solstice. It is located in the only place of the island where, in the period around the end of December (winter solstice), the arc of the sun embraces the entire 


\section{Ustica Geomorphology and Ancient Settlements}

terrestrial skyline of the island, rising to the east on the Falconiera peak, culminating in the south on the top of M. Guardia dei Turchi, and setting in the west on the relief of Monte Costa del Fallo. This phenomenon may have been used as a sort of natural calendar that allowed inhabitants to know the time of year marking the transition from prevailing darkness to light, whose notion was indispensable for planning agricultural activities and sea voyages, as well as to organize propitiatory rituals. [Foresta Martin and Magli, 2016], (Figure 15). Orlando, Tusa, and Gori [2018] performed a similar study on prehistoric villages of Aeolian island, evidencing that horizon markers linked to the landscape and the apparent movement of the Sun during the year are in many cases evident, i.e. the Middle Bronze Age Village Cala Junco of Panarea, which seems to have a complete "horizon calendar", from East to West.

In the heart of the Colombaio stack, Furlani and Foresta Martin [2019] found a large sea cave accessible through a narrow opening and not reported in the repertoire of the Ustica caves [Mannino and Ailara, 2014], (Figure 16). The measurements of the cave opening and its internal dimensions allow us to state that thanks to the lower sea level in the Middle Bronze Age, it was possible to enter it without having to swim, therefore its anthropogenic use cannot be excluded. The presence of this cave raises a question about the future stability of the structure of the stack.

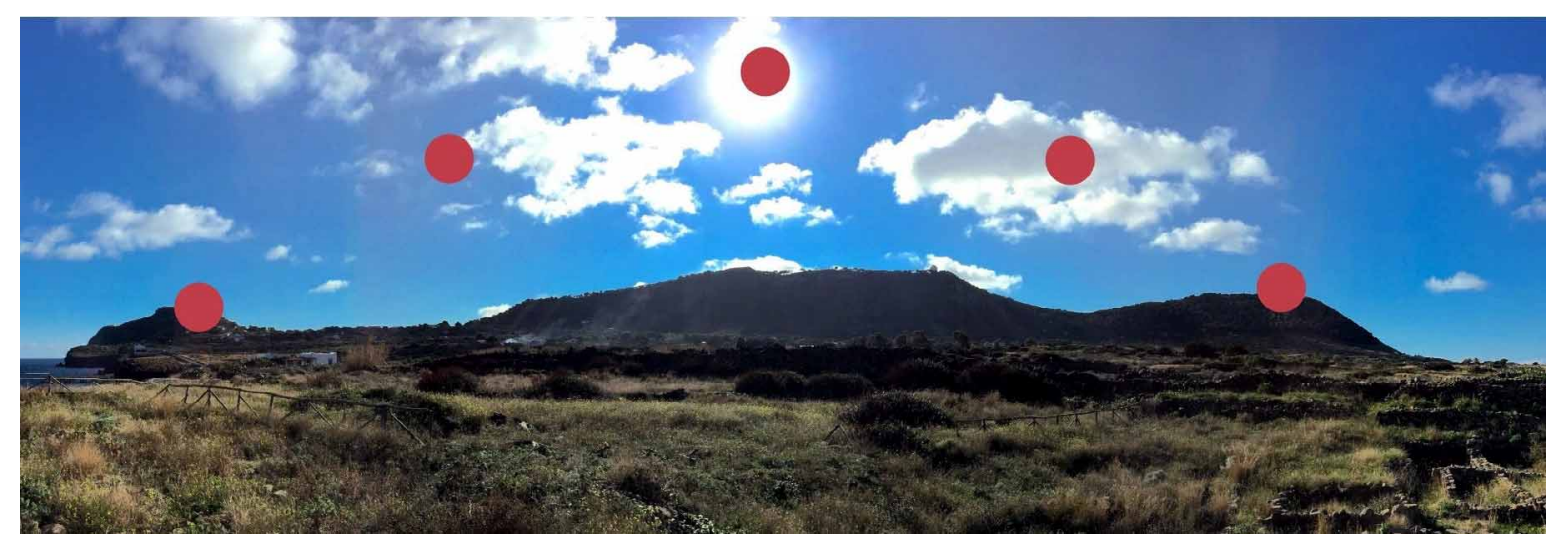

Figure 15. The Villaggio dei Faraglioni is the only place in Ustica where, in the period around the Winter Solstice, the arch of the Sun embraces the entire terrestrial profile of the island. From Foresta Martin and Magli [2016].

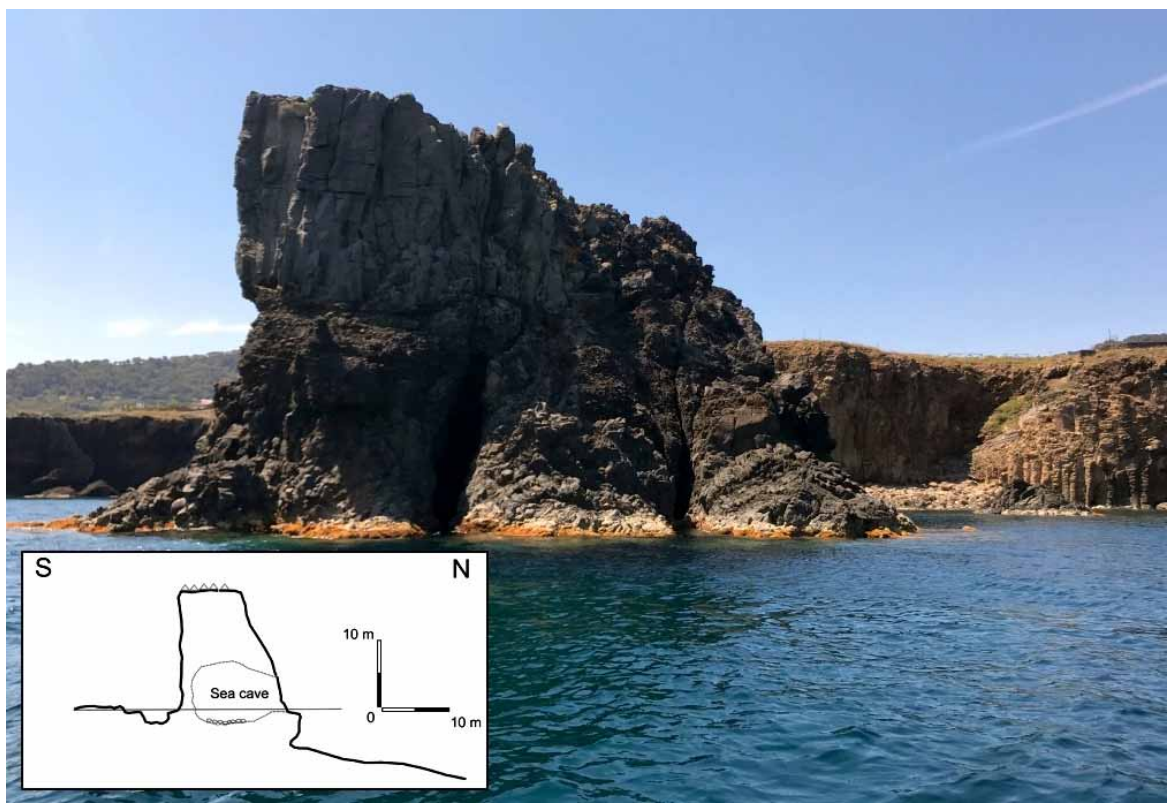

Figure 16. A narrow crack on the north side of the Faraglione Colombaio $6 \mathrm{~m}$ high and 1-2 $\mathrm{m}$ wide, leads to a large internal cavity reported for the first time by Furlani and Foresta Martin [2019]. In the insert a section of the cave on the N$\mathrm{S}$ profile. The cave is $14 \mathrm{~m}$ long and $6 \mathrm{~m}$ large; its maximum height is $9 \mathrm{~m}$ a.s.l.; the maximum depth is $-2.5 \mathrm{~m}$ a.s.l. 


\section{Franco Foresta Martin et al.}

What is important to remember is that the village was suddenly abandoned around $1200 \mathrm{BC}$, as evidenced by the fact that all belongings have been left on site. Spatafora and Mannino [2008] and Spatafora [2009], suggested that this sudden flight could be related to two hypotheses: (1) a natural disaster as an earthquake that induced the population to find a safer place; (2) a hostile invasion from the sea. Mourtzas and Kolaiti [2017] report evidence of topographic changes due to co-seismic events, or earthquakes and storms in other areas of the Mediterranean Sea. We have already explained that an earthquake should have left evidence of destruction, which is missing the defensive wall; moreover, if the site was attacked and destroyed there should be evidence of burnt layers. For these reasons, we suggest two alternative hypotheses: (1) a prolonged period of drought that forced the inhabitants to abandon the island due to the exhaustion of water reserves, compatible with the evidence of sudden decreases in rainfall in the Mediterranean area around 1200 AC [Kaniewsky et al., 2013; Incarbona et al., 2010; and references therein]; (2) an epidemic imported from outside that wiped out the already minimal population of the island. According to Norrie [2016], the most widespread diseases of this period were smallpox, bubonic plague, and tularemia (an infection transferred from rodents to humans): all capable of quickly wipe out a small prehistoric population.

\subsection{Satellites or antagonists?}

The geography of the human settlements of Ustica in the Middle Bronze Age appears to be the richest of its prehistory. In addition to the Villaggio dei Faraglioni located in the northern end of the island, which we have discussed extensively before, there were at least four other settlements: Piano dei Cardoni to the south, Omo Morto (Falconiera Crater) to the east, Spalmatore to the west, and Case Vecchie in the hinterland. But except for the Villaggio dei Faraglioni that has been repeatedly excavated in the last forty years, all the other mentioned sites are archaeologically studied only through surface surveys and collections, therefore we know nothing about their organization, nor the extent of the settlements, and their mutual relations. The geomorphological characteristics of the Middle Bronze Age settlements that are a chronological extension of previous prehistoric sites, i.e. Spalmatore and Piano dei Cardoni, have already been described before. Here we examine two other settlements whose existence has left only faint traces.

- Omo Morto Village. The remains of three huts destroyed by the construction of the wastewater purification plant at the bottom of the Falconiera crater (paragraph 2.4.5), (Figure 9), and the discovery of Middle Bronze Age pottery inside them [Mannino, 1979], suggest the existence of a settlement that occupied a small area, centered on the geographical coordinates $38.713076^{\circ} \mathrm{N}, 13.196966^{\circ} \mathrm{E}$, at a height of $35 \mathrm{~m}$ a.s.l. The site is located about thirty meters southeast of the volcano's feeding conduct (neck), now visible due to erosion and recognizable as a cluster of dark prismatic lava.

A stratigraphic section of the area where the village stood, shows a substrate formed by blocks of lavas mixed with tuffs that accumulated due to the fallout of pyroclastic products, both covered by a thin layer of marine sediments. The sediments are due to the Tyrrhenian marine transgression, which occurred around $130 \mathrm{ka}$ BP (Table I) when the Falconiera's activity was still in progress or just ended, and the northern slope of the crater collapsed into the sea [de Vita and Foresta Martin, 2017]. For a long time, the sea invaded the bottom of the crater, covering it with sediments which then, throughout geological times, turned into fertile soil. The life of this Middle Bronze Age village was the result of the overlapping of leveled and fertile soil on the rugged volcanic rocks. For this village, we can imagine both agricultural and marine vocation, with access to the sea through some small bays just west of Punta Omo Morto.

It is difficult, however, to understand the reason for this peculiar location, in such a small space, exposed to the winter north wind and almost fenced by the southern slope of the Falconiera cone, which shaded it for most of the day. The marine horizon visible from the site narrows to an arc of $80^{\circ}$ from Northwest to Northeast. The main and easiest landing on the island, Cala Santa Maria, despite being very close, is visible only by climbing on the edge of the volcanic cone, at about $150 \mathrm{~m}$ a.s.l. Probably there was a lookout post up there, connected with the village of Omo Morto and perhaps also with that of the Faraglioni, which is located only 1500 farther west. But on the top of the Falconiera, only traces of an important Hellenistic-Roman settlement $\left(4^{\text {th }}-3^{\text {rd }}\right.$ century BC) have been found until now.

- Case Vecchie settlements. The Case Vecchie district today extends over an area of about 10,000 square meters in the saddle between Monte Guardia dei Turchi and the Falconiera. The geographical coordinates of its median 


\section{Ustica Geomorphology and Ancient Settlements}

zone are $38.709807^{\circ} \mathrm{N}, 13.190531^{\circ} \mathrm{E}, 80 \mathrm{~m}$ a.s.l. (paragraph 2.4.6, Figure 9). The urban layout, with narrow streets, some of which are characterized by steep slopes, and the small houses built with the tuffs of the Falconiera date back to the Middle Ages (13th century AD), but according to the ceramic finds collected by Mannino [1970], the site would have known human occupation since the Middle Bronze Age. Its prehistoric origin is also confirmed by sporadic fragments of obsidian tools scattered throughout the area. This settlement is, among the known prehistoric ones, the closest to the current town of Ustica. From a stratigraphic point of view, the ground on which it stands bears the lavas of Monte Guardia dei Turchi at the base, with the marine deposits of the 1st order terrace superimposed (Table I). The place is sheltered from adverse winter weather conditions and far from the sea: its vocation must have been mainly agricultural, similar to that of the nearby settlement of Piano dei Cardoni. The bay of Cala Santa Maria is the closest access to the coast; the closest sources of water are represented by the dripping springs of the Grotta Azzurra and Grotta di San Francesco and by the tuff layers of the southern slope of the Falconiera. The absence of archaeological excavations does not allow to put forward other hypotheses.

\section{Conclusions}

An accurate geomorphological analysis in the broadest sense of the term, together with paleoenvironmental reconstructions, is an indispensable complement for in-depth knowledge of the foundation and development of an archaeological site. In Ustica this study is practicable and can provide a lot of additional information compared to the current knowledge framework. But the effective correlations between the geomorphological characteristics of an area and those of the human settlement built on it are limited by the scarcity of the archaeological excavations carried out so far. Of the six prehistoric settlements known and examined in the present study, only one, the Villaggio dei Faraglioni, has been repeatedly excavated and effectively described by several authors. In Piano dei Cardoni, the first excavation tests have just begun that entail systematic environmental sampling, which will provide essential information on the subsistence base of the site. Conversely, we have very partial knowledge of all the other settlements, whose understanding is entrusted only to surveys and collection of artifacts found on the surface.

Nevertheless, the analysis of the choice of settlements according to the characteristics of the territory, its geological nature, and the natural resources available, allows detecting a marked range of attitudes and vocations of the first colonizers of Ustica. Indeed, the islanders developed a range of adaptation strategies, in response to both natural and social factors, that can be read through an interdisciplinary approach, such as the one put forward in this paper. They alternated between choices of extreme caution and defense, such as those that distinguish the small human groups of Pirozza (Neolithic) and Culunnella (Ancient Bronze), and the larger community of the Faraglioni (Middle Bronze), to positions of greater openness, mastery and use of the territory, such as those expressed by Neolithic-Eneolithic and Middle Bronze Age groups in the long-lasting settlement of Piano dei Cardoni. In the latter, the richness of in the stratum finds, whose analyses are in progress [Speciale et al., 2021a,b], yet reveals a local use of mineral resources (lava, pumice, clays) for the construction of lithic tools and pottery. The distance from the sea, not only in metric terms but also of accessibility, sometimes expresses clearly agricultural vocations, even on a small island like Ustica.

Above all, the prudent use of the scarce water available dominated the entire period of prehistory, since the Neolithic. Raindrops and drops from dripping caves were carefully collected one by one, to remedy the structural lack of underground springs; and in many cases, they made the difference between extinction and survival.

A summary of the geomorphological, naturalistic, and environmental data collected for each prehistoric settlement ascertained on the island of Ustica is presented in Table 4. 
Franco Foresta Martin et al.

\begin{tabular}{|c|c|c|c|c|c|c|c|c|}
\hline $\begin{array}{l}\text { SETTLEMENT } \\
\text { NAME AND } \\
\text { LOCALITY }\end{array}$ & $\begin{array}{l}\text { COORDINATES } \\
\text { AND } \\
\text { ELEVATION * }\end{array}$ & AREA sqm & $\begin{array}{c}\text { OCCUPATION } \\
\text { ЕРОСH }\end{array}$ & $\begin{array}{l}\text { GEOLOGICAL } \\
\text { FRAMEWORK }\end{array}$ & $\begin{array}{c}\text { WATER } \\
\text { RESOURCES }\end{array}$ & $\begin{array}{c}\text { NEAREST } \\
\text { AGRICOLTURAL } \\
\text { AREA }\end{array}$ & $\begin{array}{l}\text { MARINE } \\
\text { HORIZON } \\
\text { VIEW }\end{array}$ & $\begin{array}{l}\text { NEAREST } \\
\text { COVES }\end{array}$ \\
\hline $\begin{array}{l}\text { Pirozza, } \\
\text { Spalmatore }\end{array}$ & $\begin{array}{c}38.696710^{\circ} \mathrm{N}, \\
13.157273^{\circ} \mathrm{E}, \\
49 \mathrm{~m} \text { a.s.l. }\end{array}$ & 1500 sqm & NEOLITHIC & $\begin{array}{c}\text { Crotonian } \\
\text { (240 ka BP) marine } \\
\text { terrace, on Villaggio } \\
\text { di Spalmatore trachi- } \\
\text { basaltic columnar } \\
\text { lavas ( } 320 \mathrm{ka} \mathrm{BP})\end{array}$ & $\begin{array}{l}\text { Freshwater dripping } \\
\text { from the walls of } \\
\text { Grotta Pirciata and } \\
\text { Grotta della Fossa } \\
\text { caves }\end{array}$ & $\begin{array}{l}\text { Villaggio di } \\
\text { Spalmatore } \\
\text { adjoining area }\end{array}$ & $\begin{array}{c}220^{\circ} \text { : from SSE } \\
\left(160^{\circ}\right) \\
\text { to } \operatorname{NNE}\left(20^{\circ}\right)\end{array}$ & $\begin{array}{c}\text { Punta dello } \\
\text { Spalmatore, } \\
\text { Caletta } \\
\text { Santoro, Punta } \\
\text { Cavazzi }\end{array}$ \\
\hline $\begin{array}{l}\text { Villaggio } \\
\text { Turistico, } \\
\text { Spalmatore }\end{array}$ & $\begin{array}{l}38.697653^{\circ} \mathrm{N}, \\
13.158064^{\circ} \mathrm{E}, \\
30-40 \mathrm{~m} \text { a.s.l. }\end{array}$ & $\sim 50000 \mathrm{sqm}$ & $\begin{array}{l}\text { ENEOLITHIC- } \\
\text { BRONZE AGE }\end{array}$ & $\begin{array}{c}\text { Tyrrhenian } \\
\text { (130 ka BP) marine } \\
\text { terrace, on Villaggio } \\
\text { di Spalmatore trachi- } \\
\text { basaltic columnar } \\
\text { lavas ( } 320 \mathrm{ka} \mathrm{BP)}\end{array}$ & $\begin{array}{l}\text { Fresh water dripping } \\
\text { from the walls of } \\
\text { Grotta Segreta and } \\
\text { Grotta Pirciata caves }\end{array}$ & $\begin{array}{l}\text { Villaggio di } \\
\text { Spalmatore } \\
\text { adjoining area }\end{array}$ & $\begin{array}{c}150^{\circ} \text { : from S } \\
\left(190^{\circ}\right) \\
\text { to } \operatorname{NNW}\left(340^{\circ}\right)\end{array}$ & $\begin{array}{c}\text { Punta dello } \\
\text { Spalmatore, } \\
\text { Caletta } \\
\text { Santoro, Punta } \\
\text { Cavazzi }\end{array}$ \\
\hline $\begin{array}{c}\text { Piano dei } \\
\text { Cardoni, Piano } \\
\text { dei Cardoni } \\
\text { Sopravia }\end{array}$ & $\begin{array}{c}38.705483^{\circ} \mathrm{N}, \\
13.1893^{\circ} \mathrm{E}, \\
90 \mathrm{~m} \text { asl } \\
38.7062472^{\circ} \mathrm{N} \\
13.1888138^{\circ} \mathrm{E} \\
102 \mathrm{~m} \text { asl }\end{array}$ & Indeterminate & $\begin{array}{l}\text { NEOLITHIC- } \\
\text { ENEOLITHIC- } \\
\text { BRONZE AGE }\end{array}$ & $\begin{array}{c}\text { Crotonian } \\
(\sim 350 \text { ka BP }) \text { marine } \\
\text { terrace deposits, } \\
\text { superimposed on } \\
\text { Monte Guardia dei } \\
\text { Turchi basaltic flows } \\
(\sim 520 \mathrm{ka} \mathrm{BP})\end{array}$ & $\begin{array}{l}\text { Fresh water dripping } \\
\text { from the walls of } \\
\text { Grotta Azzurra, } \\
\text { Grotta di San } \\
\text { Francesco and Mount } \\
\text { Falconiera southern } \\
\text { slope caves }\end{array}$ & $\begin{array}{l}\text { Piano dei Cardoni } \\
\text { Sopravia area }\end{array}$ & $\begin{array}{c}208^{\circ}: \text { from NE } \\
\left(35^{\circ}\right) \\
\text { to SW }\left(243^{\circ}\right)\end{array}$ & $\begin{array}{l}\text { Cala Santa } \\
\text { Maria }\end{array}$ \\
\hline $\begin{array}{l}\text { Culunnella, } \\
\text { Monte Guardia } \\
\text { dei Turchi }\end{array}$ & $\begin{array}{l}38.710202^{\circ} \mathrm{N}, \\
13.193225^{\circ} \mathrm{E}, \\
238 \mathrm{~m} \text { a.s.l. }\end{array}$ & 2000 sqm & $\begin{array}{c}\text { ANCIENT } \\
\text { BRONZE AGE }\end{array}$ & $\begin{array}{c}\text { Relict of Monte } \\
\text { Guardia dei Turchi } \\
\text { vulcanic crater }(\sim 500 \\
\text { ka BP). Basalt } \\
\text { basement with } \\
\text { superimposed thin } \\
\text { layers of Monte } \\
\text { Costa del Fallo tuffs } \\
\text { and Grotte del Lapillo } \\
\text { tephra }\end{array}$ & $\begin{array}{l}\text { Fresh water dripping } \\
\text { from the walls of } \\
\text { Grotta Azzurra, } \\
\text { Grotta di San } \\
\text { Francesco and Mount } \\
\text { Falconiera southern } \\
\text { slope caves }\end{array}$ & $\begin{array}{l}\text { Piano dei Cardoni } \\
\text { Sopravia area }\end{array}$ & $\begin{array}{l}360^{\circ} \text { : all-round } \\
\text { view of the } \\
\text { marine horizon }\end{array}$ & $\begin{array}{c}\text { Cala Santa } \\
\text { Maria, } \\
\text { Cala del } \\
\text { Camposanto }\end{array}$ \\
\hline $\begin{array}{l}\text { Villaggio dei } \\
\text { Faraglioni, } \\
\text { Tramontana }\end{array}$ & $\begin{array}{c}38.718972^{\circ}, \\
13.182170^{\circ}, \\
18 \mathrm{~m} \text { a.s.l. }\end{array}$ & 7500 sqm & $\begin{array}{c}\text { MIDDLE } \\
\text { BRONZE AGE }\end{array}$ & $\begin{array}{c}\text { Tyrrhenian } \\
\text { (130 ka BP) marine } \\
\text { terrace, on Gorgo } \\
\text { Salato basaltic } \\
\text { columnar lavas ( } 325 \\
\text { ka BP), and } \\
\text { Tramontana trachi- } \\
\text { andesitic columnar } \\
\text { lavas (320 ka BP) }\end{array}$ & $\begin{array}{l}\text { Rainwater collected } \\
\text { in wells dug inside } \\
\text { the village, and } \\
\text { freshwater dripping } \\
\text { in Grotta Azzurra, } \\
\text { Grotta di San } \\
\text { Francesco, and } \\
\text { Falconiera southern } \\
\text { slope caves }\end{array}$ & Tramontana area & $\begin{array}{c}181^{\circ} \text { : from ESE } \\
\left(111^{\circ}\right) \\
\text { to WNW }\left(292^{\circ}\right)\end{array}$ & $\begin{array}{c}\text { Punta del } \\
\text { Gorgo Salato } \\
\text { bay }\end{array}$ \\
\hline $\begin{array}{l}\text { Villaggio } \\
\text { del'Omo Morto, } \\
\text { Falconiera }\end{array}$ & $\begin{array}{l}38.713076^{\circ} \mathrm{N} \\
13.196966^{\circ} \mathrm{E} \\
35 \mathrm{~m} \text { a.s.l. }\end{array}$ & Indeterminate & $\begin{array}{c}\text { MIDDLE } \\
\text { BRONZE AGE }\end{array}$ & $\begin{array}{l}\text { Tyrrhenian } \\
\text { (130 ka BP) marine } \\
\text { terrace, on Falconiera } \\
\text { lava and tuffs } \\
\text { (130 ka BP) }\end{array}$ & $\begin{array}{l}\text { Rainwater collected } \\
\text { in wells dug inside } \\
\text { the village, and } \\
\text { freshwater dripping } \\
\text { in Grotta Azzurra, } \\
\text { Grotta di San } \\
\text { Francesco, and } \\
\text { Falconiera southern } \\
\text { slope caves }\end{array}$ & $\begin{array}{c}\text { Falconiera crater } \\
\text { area }\end{array}$ & $\begin{array}{c}80^{\circ}: \text { from NW } \\
\left(320^{\circ}\right) \\
\text { to } \mathrm{NE}\left(40^{\circ}\right)\end{array}$ & $\begin{array}{c}\text { Cala del } \\
\text { Camposanto, } \\
\text { Cala S. Maria }\end{array}$ \\
\hline $\begin{array}{l}\text { Case Vecchie, } \\
\text { Petriera, Piano } \\
\text { dei Cardoni }\end{array}$ & $\begin{array}{c}38.709807^{\circ} \mathrm{N} \\
13.190531^{\circ} \mathrm{E} \\
\text { 80m a.s.l. }\end{array}$ & Indeterminate & $\begin{array}{c}\text { MIDDLE } \\
\text { BRONZE AGE }\end{array}$ & $\begin{array}{c}\text { Crotonian } \\
(\sim 350 \text { ka BP) marine } \\
\text { terrace deposits, } \\
\text { superimposed on } \\
\text { Monte Guardia dei } \\
\text { Turchi basaltic flows } \\
(\sim 520 \text { kyrs BP })\end{array}$ & $\begin{array}{l}\text { Rainwater collected } \\
\text { in wells dug inside } \\
\text { the village, and } \\
\text { freshwater dripping } \\
\text { in Grotta Azzurra, } \\
\text { Grotta di San } \\
\text { Francesco, and } \\
\text { Falconiera southern } \\
\text { slope caves }\end{array}$ & $\begin{array}{l}\text { Petriera and Piano } \\
\text { dei Cardoni area }\end{array}$ & $\begin{array}{l}40^{\circ}: \\
\text { from } \mathrm{E}\left(90^{\circ}\right) \\
\text { to } \operatorname{SE}\left(130^{\circ}\right)\end{array}$ & Cala S. Maria \\
\hline
\end{tabular}

Table 4. Geomorphological and archaeological data concerning prehistoric settlement. 


\section{References}

Anzidei, M., K. Lambeck, F. Antonioli, S. Furlani, G. Mastronuzzi, E. Serpelloni and G. Vannucci (2014), Coastal structure, sea-level changes and vertical motion of the land in the Mediterranean, Geological Society, London, Special Publications, 388, 1, 453-479.

Barberi, F., S. Borsi, G. Ferrara and F. Innocenti (1969). Strontium isotopic composition of some recent basic volcanites from southern Tyrrhenian sea and Sicily Channel, Contr. Mineral. Petrol., 23, 157-172.

Barberi, F. and F. Innocenti (1980). Volcanisme Neogéne et Quaternaire. Guide a l'excursion 122-A, Soc. It. Miner. Petrol., 99-104.

Benjamin, J., A. Rovere, A. Fontana, S. Furlani, M. Vacchi, R.H. Inglis and R. Gehrels, (2017). Late Quaternary sea-level changes and early human societies in the central and eastern Mediterranean Basin: an interdisciplinary review, Quaternary International, 449, 29-57.

Buccheri, G., C. D’Arpa and F. Foresta Martin (2014). A geosite to be saved: the Tyrrhenian fossil deposit on the island of Ustica, Naturalista Sicil., S. IV, XXXVIII, 179-191.

Calcara, P. (1842). Descrizione dell'isola di Ustica, Giornale Letterario, 22, Palermo.

Cinque, A., L. Civetta, G. Orsi and A. Peccerillo (1988). Geology and geochemistry of the island of Ustica (Southern Tyrrhenian Sea), Rend. Soc. It. Min. e Petr., 43, 987-1002.

Counts, D.B. and A.S. Tuck (2009). Discovery and Discourse: Archaeology and Interpretation, In: KOINE: Mediterranean Studies in Honor of R. Ross Holloway, Oxbow Books, Oxford.

Dawson, H. (2014). Mediterranean voyages. The archaeology of island colonisation and abandonment, Left Coast Press, Inc., Walnut Creek, CA, USA.

D’Asburgo L.S. (1898). Ustica, Giada, Palermo.

Delpino, M. F. and M. Mineo (1995). La piroga neolitica del lago di Bracciano (“La Marmotta 1”), Bullettino di paletnologia italiana, 86, 197-266.

de Vita, S. (1993). Assetto geologico-strutturale ed evoluzione vulcanologica dell'isola di Ustica stratigrafia, tettonica e meccanismi eruttivi), PhD Thesis, Napoli, 162.

de Vita, S. and G. Orsi (1994). I terrazzi marini dell'isola di Ustica (Mar Tirreno Meridionale, Italia), Mem. Descr. Carta Geol. D’It., 52, 405-406.

de Vita, S., G. Guzzetta and G. Orsi (1995). Deformational features of the Ustica volcanic area in the Southern Tyrrhenian Sea (Italy), Terra Nova, 7, 623-629.

de Vita, S., M.A. Laurenzi, G. Orsi and M. Voltaggio (1998). Application of 40Ar/39Ar and 230Th dating methods to the chronostratigraphy of Quaternary basaltic volcanic areas: the Ustica island case history, Quat. Int., 47/48, 117-127.

de Vita, S. and F. Foresta Martin (2017). The palaeogeographic setting and the local environmental impact of the $130 \mathrm{ka}$ Falconiera tuff-cone eruption (Ustica island, Italy), Ann. Geophys., 60, 2, https://doi.org/10.4401/ag-7113

Di Stefano C.A. and G. Mannino (1983). Carta archeologica della Sicilia, Carta d'Italia, F. 249, Palermo.

Foresta Martin, F. (2001). Emissioni di vapor d'acqua e di gas endogeni da bocche e fessure nei terreni dell'isola di Ustica, Il Naturalista Siciliano, IV, XXV, 1-2, 15-25.

Foresta Martin, F. (2014). Ustica prima dell’Uomo, Centro Studi e Documentazione Isola di Ustica, Palermo, 70.

Foresta Martin, F. (2015). Un periplo dell'isola fra cuscini di lava, antiche colate laviche, banchi di tufo e grotte. Lettera del Centro Studi e Documentazione Isola di Ustica, 48-49, 10-13.

Foresta Martin, F. and G. Magli (2016). Astronomy and landscape at the prehistoric settlement Villaggio dei Faraglioni, Ustica, Sicily, Mediterranean Archaeology and Archaeometry, 16, 2, 167-172.

Foresta Martin, F. and R. Tykot (2019). Characterization and Provenance of Archaeological Obsidian from PirozzaSpalmatore, a Site of Neolithic Colonization on the Island of Ustica (Sicily), Open Archaeology, 5, 4-17.

Foresta Martin, F. and M. La Monica (2019). The Black Gold that came from the sea. A review of Obsidian studies at the island of Ustica, Ann. Geophys., 62, 1, https://doi.org/10.4401/ag-7686.

Furlani, S. (2020). Integrated observational targets and instrumental data on rock coasts through snorkel surveys, Marine Geol., 245, 106191, 1-15.

Furlani, S., F. Antonioli, D. Cavallaro, P. Chirco, F. Caldareri, F. Foresta Martin and M. Agate (2017). Tidal notches, coastal landforms and relative sea-level changes during the Late Quaternary at Ustica Island (Tyrrhenian Sea, Italy), Geomorphology, 299, 94-106.

Furlani, S., and F. Foresta Martin. (2019). Headland or stack? Paleogeographic reconstruction of the coast at the Faraglioni 


\section{Franco Foresta Martin et al.}

Middle Bronze Age Village (Ustica island, Italy), Annals of Geophysics, 62, 1, https://doi.org/10.4401/ag-7748

Held, S.O. (1989). Colonization cycles on Cyprus 1: The biogeographic and paleontological foundations of early prehistoric settlement, Report of the Department of Antiquities, Cyprus, 1989, 7-28.

Holloway, R.R. (2002). The archaeology of ancient Sicily. Routledge.

Holloway, R.R. and S.S. Lukesh (1995). Ustica I: Excavations of 1990 and 1991, Archaeologia Transatlantica, XIV, Brown University Center for Old World Archaeology and Art.

Holloway, R. R., and Lukesh, S. S. (2001). Ustica II: The Results of the Excavations of the Regione Siciliana Soprintendenza ai Beni Culturali ed Ambientali Provincia di Palermo in Collaboration with Brown University in 1994 and 1999. Center for Old World Archaeology and Art, Brown University, $19 \mathrm{v}$.

Holloway, R. R. and S. S. Lukesh, (1997). Ustica, località Faraglioni: Perché Castello. Archeologia e territorio, 455-460.

Incarbona, A., M. Agate, G. Arisco, S. Bonomo, G. Buccheri, C. Di Patti and G. Zarcone (2010). Ambiente e clima della Sicilia durante gli ultimi 20 mila anni, Il Quaternario, It. J. Quaternary Sci., 23, 21-36.

Kaniewski, D., E. Van Campo, J. Guiot, S. Le Burel, T. Otto, and C. Baeteman (2013). Environmental roots of the Late Bronze Age crisis, PloS one, 8, 8, e71004.

Kuhn, G. G. and F. P. Shepard (1984). Sea Cliffs, Beaches and Coastal Valleys of San Diego County, Univ. of Calif.

Leighton, R. (2004). Fortress Ustica? An Island World in the Bronze Age, Am. J. Archaeology, 103-106.

Lo Presti, V., F. Antonioli, M.R. Palombo, V. Agnesi, S. Biolchi, L. Calcagnile, C. Di Patti, S. Donati, S. Furlani, J. Merizzi, F. Pepe, G. Quarta, P. Renda, A. Sulli, S. Tusa, (2019). Palaeogeographical evolution of the Egadi Islands (western Sicily, Italy). Implications for late Pleistocene and early Holocene sea crossings by humans and other mammals in the western Mediterranean, Earth-Sci. Rev., 194, 160-181.

Mannino, G. (1970). Ustica, Sicilia Archeologica, 11, 37-41.

Mannino, G. (1979). Ustica. Risultati di esplorazioni archeologiche, Sicilia Archeologica, 41, 7-40.

Mannino, G. (1982). Il Villaggio dei Faraglioni di Ustica, notizie preliminari, Studi in onore di Ferrante Rittatore Vonwiller. Como, I.

Mannino, G. (1991). Ustica: Nuove e più antiche testimonianze archeologiche, Sicilia Archeologica, 75, 65-85.

Mannino, G. (1997). Ustica, Luxograph, Palermo.

Mannino, G. (1998a). Il Neolitico nel Palermitano e la nuova scoperta nell'isola di Ustica, Quaderni del Museo Archeologico Regionale “Antonio Salinas", 4, 45-80.

Mannino, G. (1998b). La grotta del fumo ed i Vuccaroli di Ustica, Newsletter del Centro Studi e Documentazione Isola di Ustica, 4, 21-23.

Mannino, G. (2007a). Guida alla preistoria del palermitano: elenco dei siti preistorici della provincia di Palermo, Istituto Siciliano di studi politici ed economici, Palermo.

Mannino, G. (2007b). Larcheologia sulla Falconiera, Lettera del Centro Studi e Documentazione Isola di Ustica. 23-24, 32-40.

Mannino, G. (2008). Culunnella: il villaggio e la necropoli dell'Antica Età del Bronzo, Lettera del Centro Studi e Documentazione Isola di Ustica, 28-29, 1-6.

Mannino, G. (2015). La scoperta del Neolitico a Ustica, Lettera del Centro Studi e Documentazione Isola di Ustica, 4849, 30-35.

Mannino, G. and V. Ailara, V. (2014). Le grotte di Ustica, Centro Studi e Documentazione Isola di Ustica.

Mannino, G. and V. Ailara, (2016). Carta archeologica di Ustica, Centro Studi e Documentazione Isola di Ustica, 87.

Martinelli, G. (1910). La sismicità all'isola di Ustica e il periodo marzo-aprile 1906, Annali Ufficio Centrale Meteorologioco e Geodinamico Italiano, XXX, I, Roma.

Martinelli, M.C., (2021). Isole vicine. L'arcipelago delle isole Eolie e le comunità umane nella preistoria mediterranea, Edizioni di storia e studi sociali, Ragusa.

Mineo, M. (2016). Monossili d'Europa: costruite anche per le rotte marine? Scienze dell'Antichità, 22, 2, 454-473.

Mourtzas, N., and E. Kolaiti, (2017). Shoreline reconstruction of the submerged Minoan harbour morphology in the bay of Kato Zakros (Eastern Crete, Greece), Journal of Archaeological Science: Reports, 12, 684-698.

Norrie, P. (2016). How Disease Affected the End of the Bronze Age. In A History of Disease in Ancient Times, Palgrave Macmillan, Cham, 61-101.

Orlando, A., S. Tusa, and D. Gori, (2018). The Prehistoric Villages of the Aeolian Archipelago and Milazzo: Astronomy and Landscape, Preliminary Result, Med. Archaeol. Archaeom., 18, 4, 219-226.

Patton, M. (1996). Islands in time: island sociogeography and Mediterranean prehistory, London, Routledge.

Peccerillo, A. (2005). Plio-quaternary volcanism in Italy, Springer-Verlag Berlin Heidelberg, 365. 
Pigonati A. (1762). Topografia dell'isola di Ustica ed antica abitazione di essa, in Opuscoli di Autori Siciliani,VII, Palermo. Reed, B., and B. Reed (2013). How much water is needed in emergencies-Technical notes on drinking water, sanitation and hygiene in emergencies. WHO, Water, Engineering and Development Centre, Loughborough Univ., Leicestershire, UK.

Romano, R. and C. Sturiale (1971). Lisola di Ustica. Studio geo-vulcanologico e magmatologico, Riv.Min. Sic., 22, 127-129. Russo, M. (1875). Memoria dell'Isola di Ustica, Nuove Effemeridi Siciliane, I, 1, Palermo.

Santi, P., F. Foresta Martin, F. Spatafora, S. de Vita and A. Renzulli (2020). Volcanic Grinding Tools in Ustica Island (Tyrrhenian Sea, Italy): Local Production vs. Import of Morgantina-Type Millstones in the Hellenistic-Roman Period, Minerals, 10, 5, 389.

Spatafora, F. (2005). Ustica e le rotte tirreniche. Il Villaggio dei Faraglioni (campagne di scavo 2003-2004). In Les Lingots peau-de-boeuf et la navigation en Mediterranee Centrale, Actes du II Colloque international (Lucciana, Mariana 15-18 settembre 2005), 133-141.

Spatafora F. (2009) Ustica tra il Tirreno e la Sicilia. Storia del popolamento dell'isola dalla Preistoria all'età tardo-romana. In Carmine Ampolo Ed. Immagine e immagini della Sicilia e di altre isole del Mediterraneo antico, I, Scuola Normale Superiore Pisa, Pisa.

Spatafora F. (2016). Tra mare e terra: la preistoria di Ustica e il Villaggio dei Faraglioni, 315-326.

Spatafora F. and G. Mannino, (2008). Ustica: guida breve, Regione Siciliana, Assessorato Regionale dei Beni Culturali Ambientali e della Pubblica Istruzione.

Speciale, C., N. Larosa, G. Battaglia, S. Vassallo (2020), Ustica - Piano dei Cardoni, Notiziario di Preistoria e Protostoria, 6.2, 62-64.

Speciale, C., K.P. Freund, S. de Vita, N. Larosa, V. Forgia, G. Battaglia and S. Vassallo (2021a). Obsidian from the site of Piano dei Cardoni, Ustica (Palermo, Italy): preliminary results on the first occupation of the Island, Open Archaeology, 7, 1, 273-290.

Speciale C., G. Montana, R. Mentesana, V. Forgia, F. Mantia, G. Battaglia, M. Di Vito, S. Vassallo and S. de Vita (2021b). Materials and Tools across Volcanoes: Exploitation of Georesources in Piano 1 dei Cardoni (Ustica, Italy) during Prehistory, Annals Geophys., 64, 5, this issue.

Speciale C., N. Larosa, F. Spatafora, A.M.G. Calascibetta, G.P. Di Sansebastiano, G. Battaglia, and S. Pasta (2021c), Archaeobotanical and Historical Insights on Some Steps of Forest Cover Disruption at Ustica Island (Sicily, Italy) from Prehistory Until Present day, Environ. Archaeology, https://doi.org/10.1080/14614103.2021.1962578

Tichý, R. (2016). The Earliest Maritime Voyaging in the Mediterranean: View from Sea, Živá Archeologie, 18, 26-36.

Tusa, S. (2016). Primo Mediterraneo. Meditazioni sul mare più antico della storia, Edizioni di Storia e Studi Sociali, Ragusa.

Tusa, S. (2017). Sicilia Archeologica. I caratteri ei percorsi dell'isola dal Paleolitico all'Età del Bronzo negli orizzonti del Mediterraneo, Edizioni di storia e studi sociali, Ragusa.

Tykot, R. H. and F. Foresta Martin, F. (2020). Analysis by pXRF of Prehistoric Obsidian Artifacts From Several Sites on Ustica (Italy): Long-Distance Open-Water Distribution From Multiple Island Sources During the Neolithic and Bronze Ages, Open Archaeology, 6, 1, 348-392.

Voza G. (1972). Thapsos, primi risultati delle più recenti ricerche, Atti della XIV riunione scientifica dell'Istituto italiano di preistoria e protostoria, 186-191.

Whitehouse, R. (2016). Water turned to stone: Stalagmites and stalactites in cult caves in prehistoric Italy, Accordia Research Papers, 14, 49-62.

Zilhao, J. (2000). From the Mesolithic to the Neolithic in the Iberian Peninsula. In T. Douglas Price (ed.), Europe's first farmers, 144-82, Cambridge: Cambridge University Press.

*CORRESPONDING AUTHOR: Franco FORESTA MARTIN,

Istituto Nazionale di Geofisica e Vulcanologia, Sezione di Palermo, Italy and Laboratorio Museo di Scienze della Terra Isola di Ustica, Palermo, Italy,

e-mail:sidereus@rocketmail.com

(c) 2021 the Author(s). All rights reserved.

Open Access. This article is licensed under a Creative Commons Attribution 3.0 International 